OAK RIDGE

NATIONAL

LABORATORY

MARTRN MALUETTA
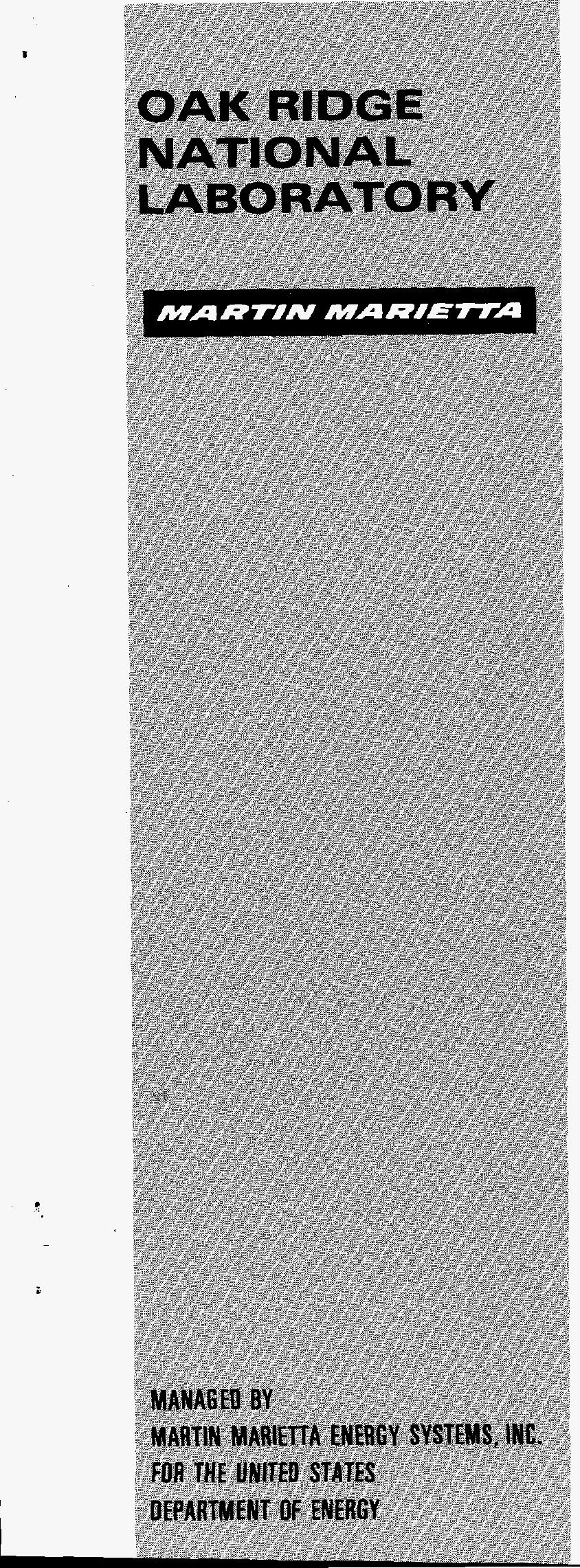

RECEIVED OCT 131995

OSTI

\section{FUEL QUALIFICATION PLAN FOR THE ADVANCED NEUTRON SOURCE REACTOR}

\author{
G. L. Copeland
}

July 1995

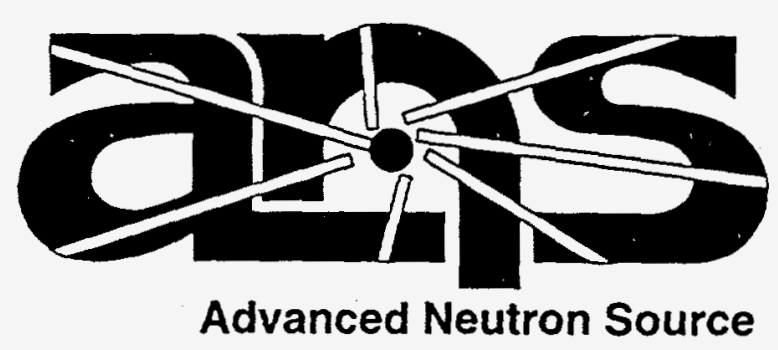

DISTRIBUTION OF THIS DOCUMENT IS UNLIMITED 
This report has been reproduced directly from the best available copy.

Available to DOE and DOE contractors from the Office of Scientific and Technical information, P.O. Box 62, Oak Ridge, TN 37831 ; prices available from (615) 576-8401, FTS 626-8401.

Available to the public from the National Technical Information Service, U.S. Department of Commerce, 5285 Port Royal Rd., Springfield, VA 22161.

This report was prepared as an account of work sponsored by an agency of the United States Government. Neither the United States Government nor any agency thereof, nor any of their employees, makes any warranty, express or implied, or assumes any legal liability or responsibility for the accuracy, completeness, or usefuiness of any information, apparatus, product, or process disclosed, or represents that its use would not infringe privately owned rights. Reference herein to any specific commercial product, process, or service by trade name, trademark, manufacturer, or otherwise, does not necessarily constitute or imply its endorsement, recommendation, or favoring by the United States Government or any agency thereot. The views and opinions of authors expressed herein do not necessarily state or reflect those of the United States Government or any agency thereof. 


\section{DISCLAIMER}

Portions of this document may be illegible in electronic image products. Images are produced from the best available original document. 



\title{
FUEL QUALIFICATION PLAN FOR THE ADVANCED NEUTRON SOURCE REACTOR
}

\author{
G. L. Copeland
}

July 1995

Prepared by

OAK RIDGE NATIONAL LABORATORY

Oak Ridge, Tennessee 37831

operated by

LOCKHEED MARTIN ENERGY SYSTEMS, INC.

for the

U.S. DEPARTMENT OF ENERGY

under contract DE-AC05-84OR21400 



\section{CONTENTS}

FIGURES $\ldots \ldots \ldots \ldots \ldots \ldots \ldots \ldots \ldots \ldots \ldots \ldots \ldots \ldots \ldots \ldots$

TABLES $\ldots \ldots \ldots \ldots \ldots \ldots \ldots \ldots \ldots \ldots \ldots \ldots \ldots \ldots \ldots \ldots \ldots \ldots \ldots$ vii

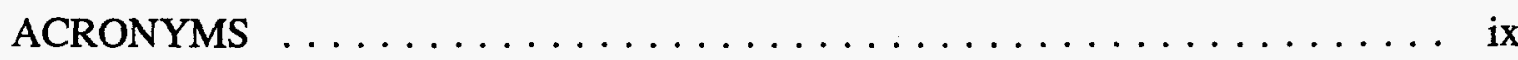

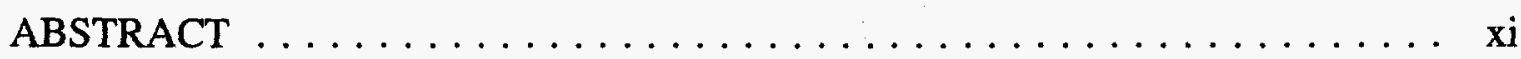

1. INTRODUCTION $\ldots \ldots \ldots \ldots \ldots \ldots \ldots \ldots \ldots \ldots \ldots \ldots \ldots \ldots \ldots \ldots$

2. STATUS OF $\mathrm{U}_{3} \mathrm{Si}_{2}$ DEVELOPMENT AT START OF PROJECT $\ldots \ldots 2$-1

3. QUALIFICATION OF FUEL FOR THE ANTICIPATED OPERATING CONDITIONS OF THE ADVANCED NEUTRON SOURCE REACTOR . . . 3-1

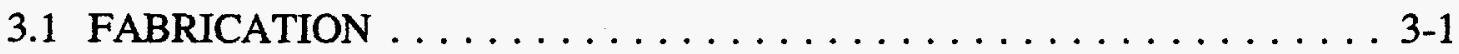

3.1.1 Fuel Distribution . . . . . . . . . . . . . . . 3-1

3.1.2 Change from Oxide to Silicide Fuel Particles . . . . . . . . 3-1

3.1.3 Inspection Technology . . . . . . . . . . . . . . . 3-3

3.2 IRRADIATION PERFORMANCE $\ldots \ldots \ldots \ldots \ldots \ldots \ldots \ldots \ldots .3-3$

3.2.1 Capsule Tests in the High Flux Isotope Reactor Target . . . . . 3-6

3.2.2 Miniplate Irradiation Tests $\ldots \ldots \ldots \ldots \ldots \ldots \ldots \ldots \ldots . . \ldots \ldots$

3.2.3 Full-Sized Plate Irradiation $\ldots \ldots \ldots \ldots \ldots \ldots \ldots \ldots \ldots . . \ldots \ldots$

3.2.4 Irradiation of Experimental $\mathrm{U}_{3} \mathrm{Si}_{2}$ Element in High Flux

Isotope Reactor . . . . . . . . . . . . . . . . . .

3.2.5 Burnable Poison Selection and Testing ........... 3-11

3.2.6 Off-Normal Fuel and Operation $\ldots \ldots \ldots \ldots \ldots \ldots \ldots \ldots .11$

4. INTERACTIONS WITH OTHER TASKS $\ldots \ldots \ldots \ldots \ldots \ldots \ldots \ldots$ 4-1

4.1 REACTOR CORE DEVELOPMENT-WBS $1.1 .1 \ldots \ldots \ldots \ldots \ldots 4$. 1

4.2 CORROSION TESTS AND ANALYSIS-WBS $1.1 .3 \ldots \ldots \ldots \ldots .4-1$

4.3 CRITICAL EXPERIMENTS-WBS $1.1 .6 \ldots \ldots \ldots \ldots \ldots \ldots$.2

4.4 MATERIAL DATA, STRUCTURAL TESTS, AND



4.5 FACILITY CONCEPTS-WBS $1.1 .13 \ldots \ldots \ldots \ldots \ldots \ldots \ldots$ 4-2

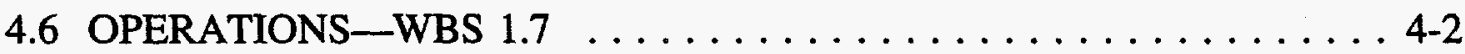


5. TESTING AND ANALYSIS OF FUEL PLATES UNDER TRANSIENT HEATUP CONDITIONS $\ldots \ldots \ldots \ldots \ldots \ldots \ldots \ldots \ldots \ldots \ldots \ldots \ldots \ldots \ldots \ldots$

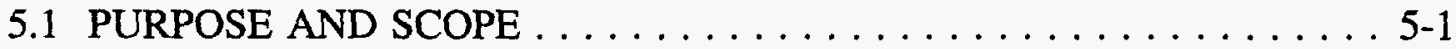

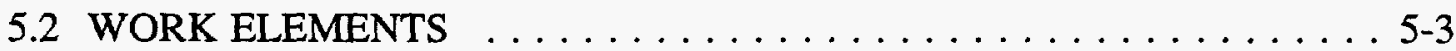

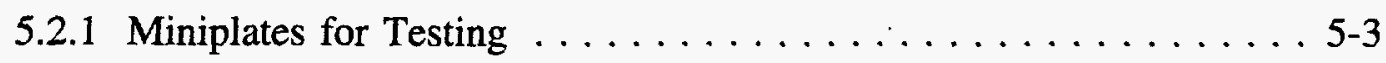

5.2 .2 Miniplate Irradiation $\ldots \ldots \ldots \ldots \ldots \ldots \ldots \ldots \ldots \ldots .7 .7$

5.2.3 Testing in Nuclear Safety Research Reactor . . . . . . . . . . 5-7

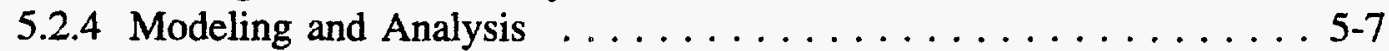

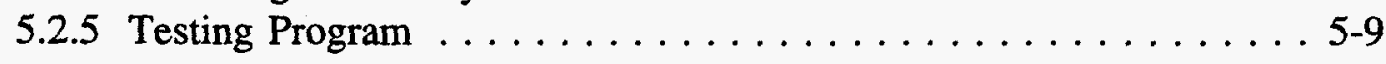

6. SCHEDULE AND COSTS $\ldots \ldots \ldots \ldots \ldots \ldots \ldots \ldots \ldots \ldots \ldots \ldots$

6.1 FUEL DEVELOPMENT_WBS $1.1 .2 \ldots \ldots \ldots \ldots \ldots \ldots \ldots \ldots 6-1$

6.2 TRANSIENT HEATUP TESTING $\ldots \ldots \ldots \ldots \ldots \ldots \ldots \ldots .6 \% \ldots$

6.2.1 Cost to Advanced Neutron Source Project . . . . . . . . 6-1

6.2 .2 Cost-Savings Estimates $\ldots \ldots \ldots \ldots \ldots \ldots \ldots \ldots \ldots \ldots$

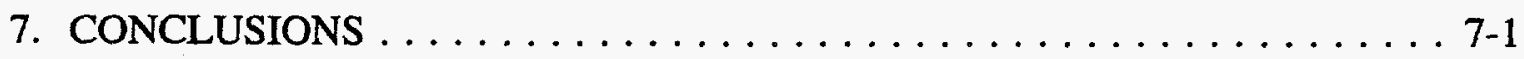

8. REFERENCES $\ldots \ldots \ldots \ldots \ldots \ldots \ldots \ldots \ldots \ldots \ldots \ldots \ldots$ 8-1 


\section{FIGURES}

Figure

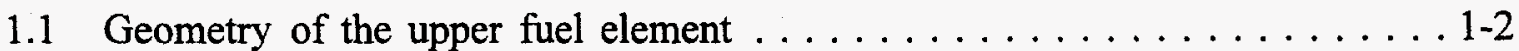

1.2 Geometry of the lower fuel element $\ldots \ldots \ldots \ldots \ldots \ldots \ldots \ldots$

1.3 Geometry of the upper fuel-element plate $\ldots \ldots \ldots \ldots \ldots \ldots \ldots$

1.4 Geometry of the lower fuel-element plate $\ldots \ldots \ldots \ldots \ldots \ldots$

1.5 Fuel grading for the $\mathrm{G} 693$ core $\ldots \ldots \ldots \ldots \ldots \ldots \ldots$

2.1 Irradiation experience (fission density in the meat) for $\mathrm{U}_{3} \mathrm{Si}_{2}$ dispersed in aluminum, showing that the data extend almost to the peak fission density in ANS . . . . . . . . . . . . . . 2-2

2.2 Irradiation experience (fission density in the fuel particles) for $\mathrm{U}_{3} \mathrm{Si}_{2}$ dispersed in aluminum, showing that, prior to the HANS-1 capsule, the peak fission density in ANS was outside the experience $\ldots \ldots \ldots . . .2-3$

2.3 Comparison of postirradiation microstructure of $\mathrm{U}_{3} \mathrm{Si}_{2} \mathrm{HEU}$ irradiated in HFIR vs HEU and LEU irradiated in ORR $(\sim 500 \mathrm{X}) \ldots \ldots \ldots \ldots \ldots . . \ldots$

2.4 Scanning electron microscopy reveals a stable gas bubble distribution in HEU plates irradiated in ORR ................ 2-6

2.5 Fuel particle swelling obtained from $\mathrm{U}_{3} \mathrm{Si}_{2}-\mathrm{Al}$ miniplates of various enrichments

3.1 Logic diagram for qualification of the fuel fabrication for ANS $\ldots \ldots$ 3-2

3.2 Logic diagram for qualification of the fuel performance for ANS $\ldots \ldots$ 3-5

3.3 Microstructure of the high-burnup $\mathrm{U}_{3} \mathrm{Si}_{2}$ HEU particles from the HANS-1 capsule and the fuel performance model calculation of the fission gas bubble distributions $\ldots \ldots \ldots \ldots \ldots \ldots \ldots \ldots . \ldots \ldots$

5.1 Logic diagram for the transient heating tests for ANS $\ldots \ldots \ldots \ldots \ldots$

5.2 Schematic representation of ANS miniplates for testing in NSRR . . . . 5-4

5.3 Schematic representation of the NSRR test capsule with ANS miniplate $\ldots 5-8$

6.1 Summary of cost estimates for WBS 1.1.2, fuel development, in thousands of dollars . . . . . . . . . . . . . . . . 6-4

6.2 Schedule for WBS 1.1 .2 , fuel development $\ldots \ldots \ldots \ldots$. . . . . . 



\section{TABLES}

Table

Page

3.1 Comparison of fuel holder characteristics by position in capsules HANS- 1 and HANS-2

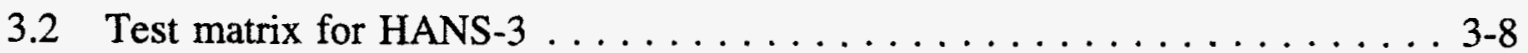

5.1 Testing and inspection criteria for ANS miniplates $\ldots \ldots \ldots \ldots \ldots$

5.2 Design parameters of ANS miniplates for NSRR tests $\ldots \ldots \ldots \ldots \ldots$

5.3 Tentative testing program for ANS miniplates in NSRR . . . . . . . 5-10

6.1 Level-four work breakdown structure tasks for fuel development . . . . . . . 6-2 



\section{ACRONYMS}

$\begin{array}{ll}\text { ANL } & \text { Argonne National Laboratory } \\ \text { ANS } & \text { Advanced Neutron Source } \\ \text { B\&W } & \text { Babcock and Wilcox } \\ \text { FSAR } & \text { final safety analysis report } \\ \text { HEU } & \text { highly enriched uranium } \\ \text { HFIR } & \text { High Flux Isotope Reactor } \\ \text { JAERI } & \text { Japan Atomic Energy Research Institute } \\ \text { LEU } & \text { low-enriched uranium } \\ \text { NSRR } & \text { Nuclear Safety Research Reactor } \\ \text { ORNL } & \text { Oak Ridge National Laboratory } \\ \text { ORR } & \text { Oak Ridge Research Reactor } \\ \text { RERTR } & \text { Reduced Enrichment Research and Test Reactor } \\ \text { SEM } & \text { scanning electron microscope } \\ \text { TREAT } & \text { transient reactor test facility } \\ \text { WBS } & \text { work breakdown structure }\end{array}$





\begin{abstract}
This report describes the development and qualification plan for the fuel for the Advanced Neutron Source. The reference fuel is $\mathrm{U}_{3} \mathrm{Si}_{2}$, dispersed in aluminum and clad in 6061 aluminum. This report was prepared in May 1994, at which time the reference design was for a two-element core containing highly enriched uranium $\left(93 \%{ }^{235} \mathrm{U}\right)$. The reactor was in the process of being redesigned to accommodate lowered uranium enrichment and became a three-element core containing a higher volume fraction of uranium enriched to $50 \%{ }^{235} \mathrm{U}$. Consequently, this report was not issued at that time and would have been revised to reflect the possibly different requirements of the lower-enrichment, higher-volume fraction fuel. Because the reactor is now being canceled, this unrevised report is being issued for archival purposes. The report describes the fabrication and inspection development plan, the irradiation tests and performance modeling to qualify performance, the transient testing that is part of the safety program, and the interactions and interfaces of the fuel development with other tasks.
\end{abstract}





\section{INTRODUCTION}

The Advanced Neutron Source (ANS) reactor is being designed as a user-oriented neutron research laboratory around the most intense continuous beams of thermal and subthermal neutrons in the world. The ANS is based on a new research reactor of about $330 \mathrm{MW}$ fission power, with an unprecedented peak neutron thermal flux of $7 \times 10^{19} \mathrm{~m}^{-2} \cdot \mathrm{s}^{-1}$. There also will be extensive facilities for materials irradiation, isotope production, and analytical chemistry.

The reactor core for the ANS consists of two cylindrical shell fuel elements. The entire core is replaced for refueling after each cycle (about $17 \mathrm{~d}$ ). Each element consists of nonfueled cylindrical side plates with involute fuel plates welded into the side plates. The fuel plates are $1.27-\mathrm{mm}$ thick, and the coolant channels are $1.27-\mathrm{mm}$ wide. The fuel plates consist of a "meat" of $\mathrm{U}_{3} \mathrm{Si}_{2}$ particles dispersed in aluminum, a "filler" section of aluminum, and a burnable poison insert on both ends, consisting of $\mathrm{B}_{4} \mathrm{C}$ particles dispersed in aluminum. The plates are clad completely with 6061 aluminum alloy, and the sideplates are 6061 alloy. The outer sideplate of the lower element coincides with the inner sideplate of the upper element. Figures 1.1 and 1.2 show the geometry of the upper and lower elements. Figures 1.3 and 1.4 show the geometry of the upper and lower plates. The fuel is graded in both the axial and the radial directions. The present reference fuel distribution is shown in Fig. 1.5.

The early core design for the ANS was a compact core with very high specific uranium density. ${ }^{1}$ The core volume was $35 \mathrm{~L}$ with a highly enriched uranium loading of about $19 \mathrm{~kg}$, necessitating a uranium loading in the meat of about $3.5 \mathrm{Mg} / \mathrm{m}^{3}$. The only promising fuel for this high density was $\mathrm{U}_{3} \mathrm{Si}_{2}$, which had been developed by the Reduced Enrichment Research and Test Reactor (RERTR) program at Argonne National Laboratory (ANL). The data upon which the U.S. Nuclear Regulatory Commission based its approval of the use of the fuel for conversion to low-enriched uranium (LEU) for licensed nonpower reactors are in Safety Evaluation Report Related to the Evaluation of Low-Enriched Uranium Silicide-Aluminum Dispersion Fuel for Use in Non-Power Reactors, NUREG-1313. ${ }^{2}$ The fuel has been shown to perform well at loadings and fission densities beyond those required for the ANS core. The ANS fission rate and temperature conditions are beyond the existing data, so an irradiation testing program is in place to verify the performance at conditions as near as possible to those of ANS. A fuel performance model is being developed to consolidate data from the various types of tests and to predict the performance of the fuel under various conditions.

The ANS conceptual core design ${ }^{3}$ is both larger and loaded lower than the original compact core. These alterations lower the uranium density to the level where both $\mathrm{U}_{3} \mathrm{O}_{8}$ and $\mathrm{UAl}_{\mathrm{x}}$ can be fabricated as dispersions in aluminum. (The current loading is about $1.7 \mathrm{Mg} / \mathrm{m}^{3}$, which is expected to be sufficient excess reactivity to account for the losses because of experimental facilities in the reflector.) Much irradiation data and experience exist for these fuels in research and test reactors. However, this irradiation experience is also at much lower temperatures and fission rates than in ANS. It was decided to retain $\mathrm{U}_{3} \mathrm{Si}_{2}$ as the reference fuel for the ANS because the higher particle 


\section{1-2}

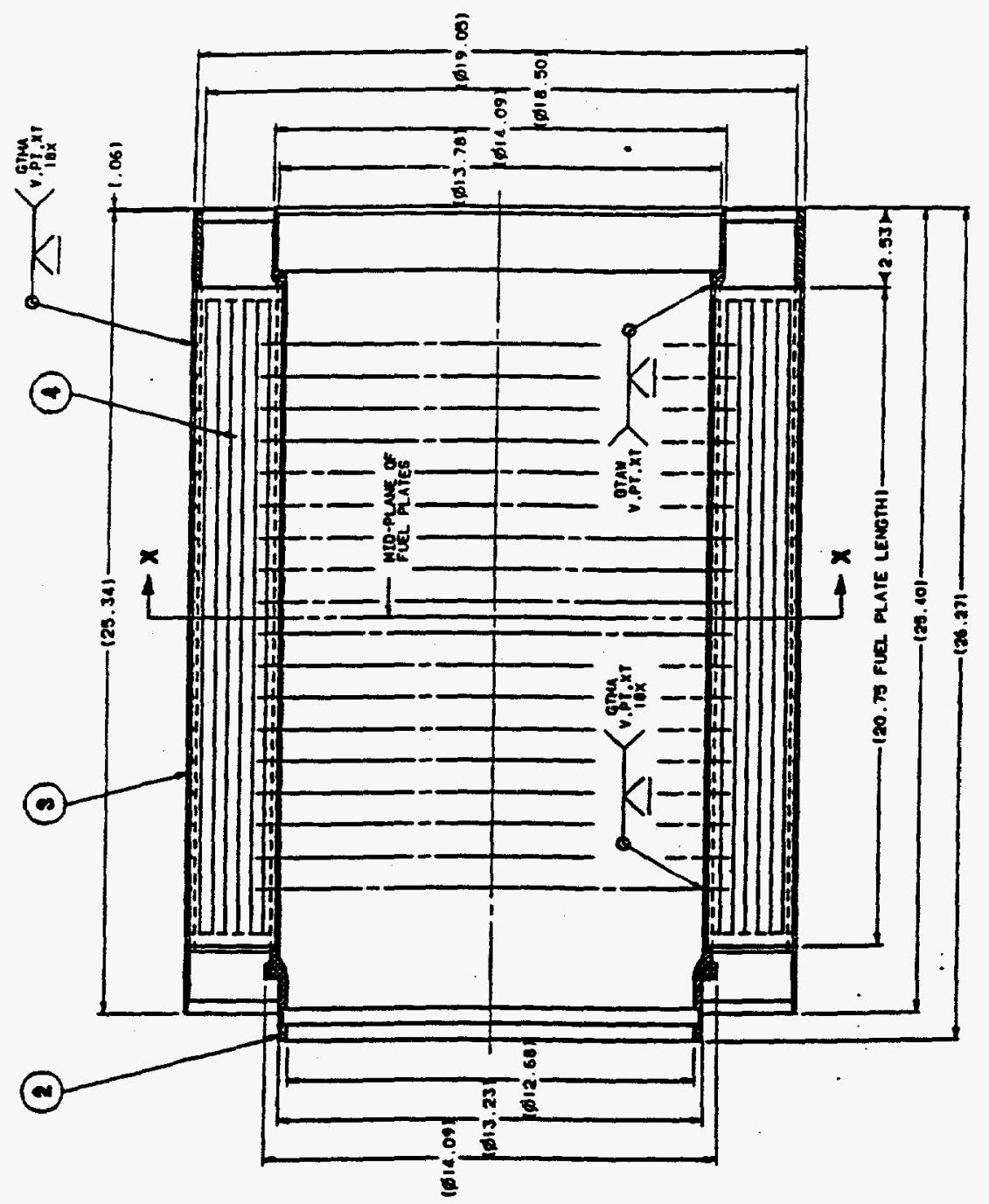

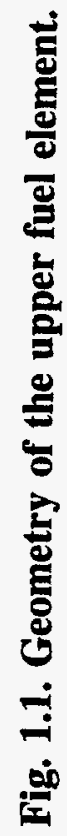



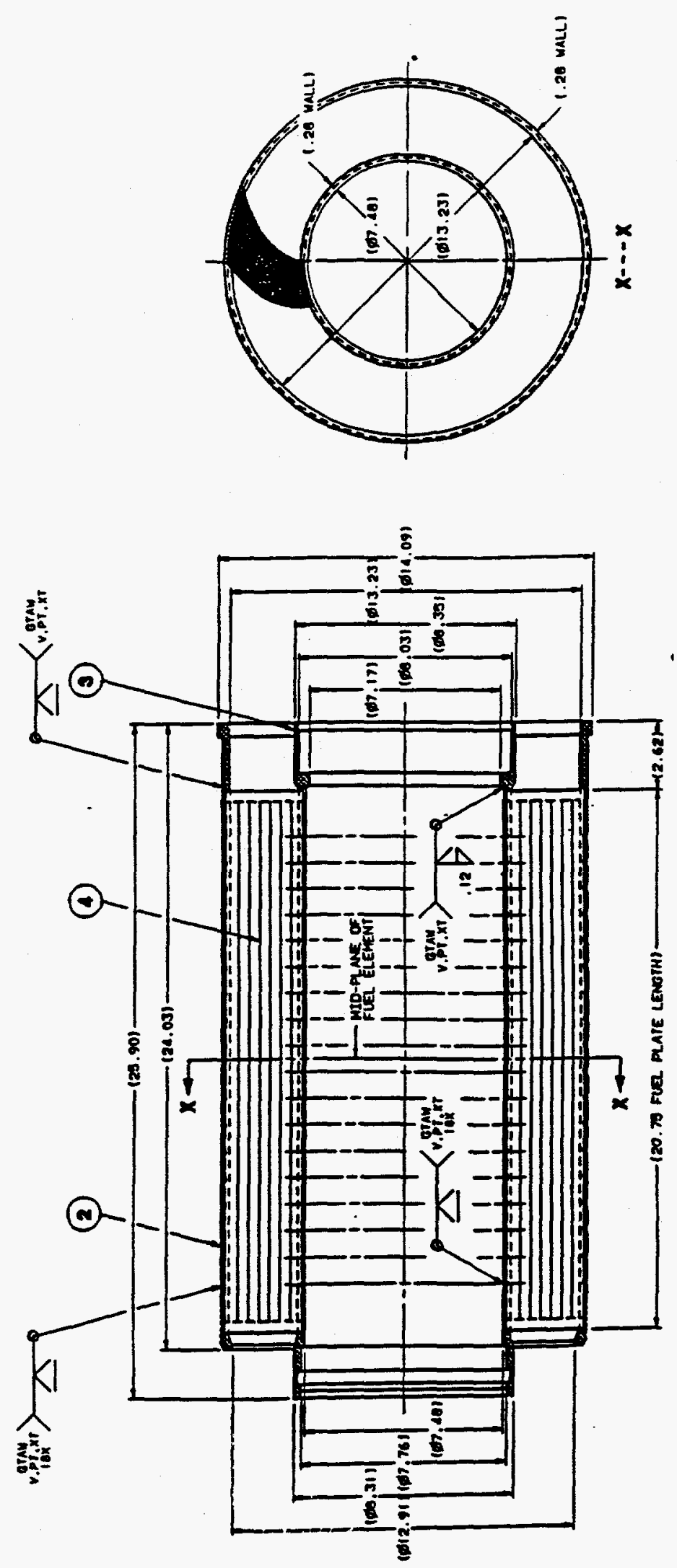

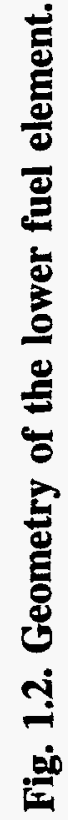



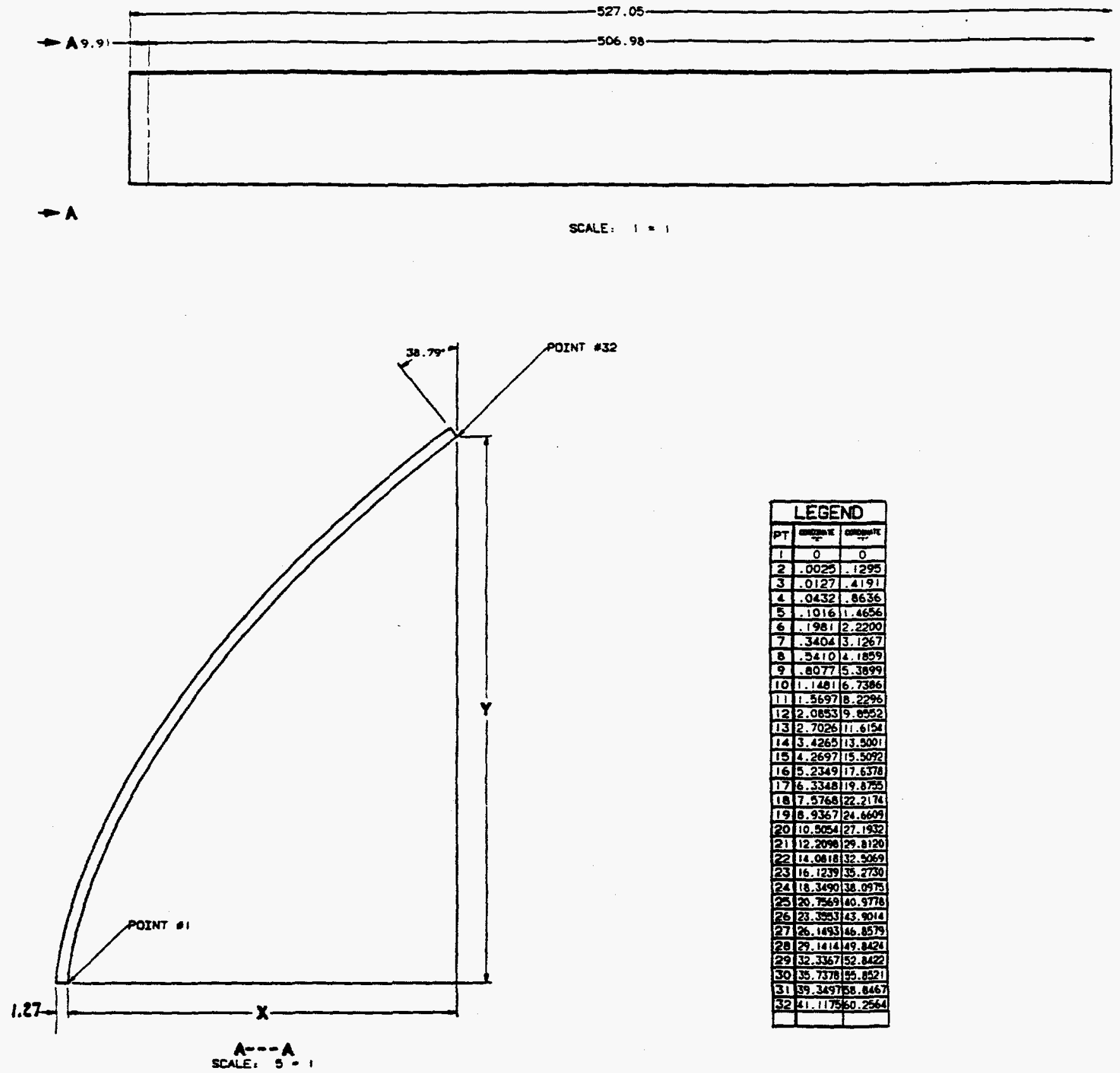

Fig. 1.3. Geometry of the upper fuel-element plate. 

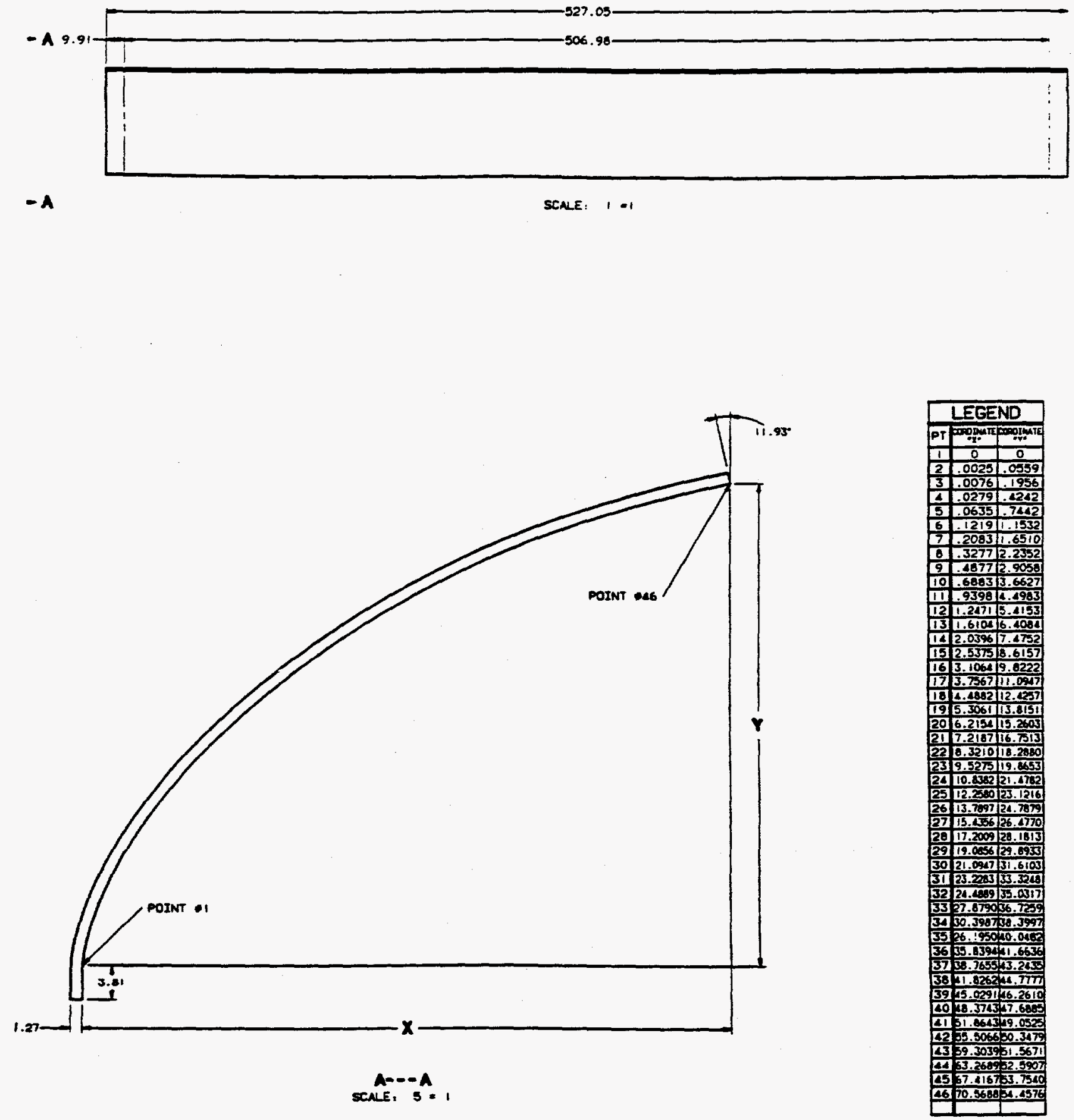

Fig. 1.4. Geometry of the lower fuel-element plate. 


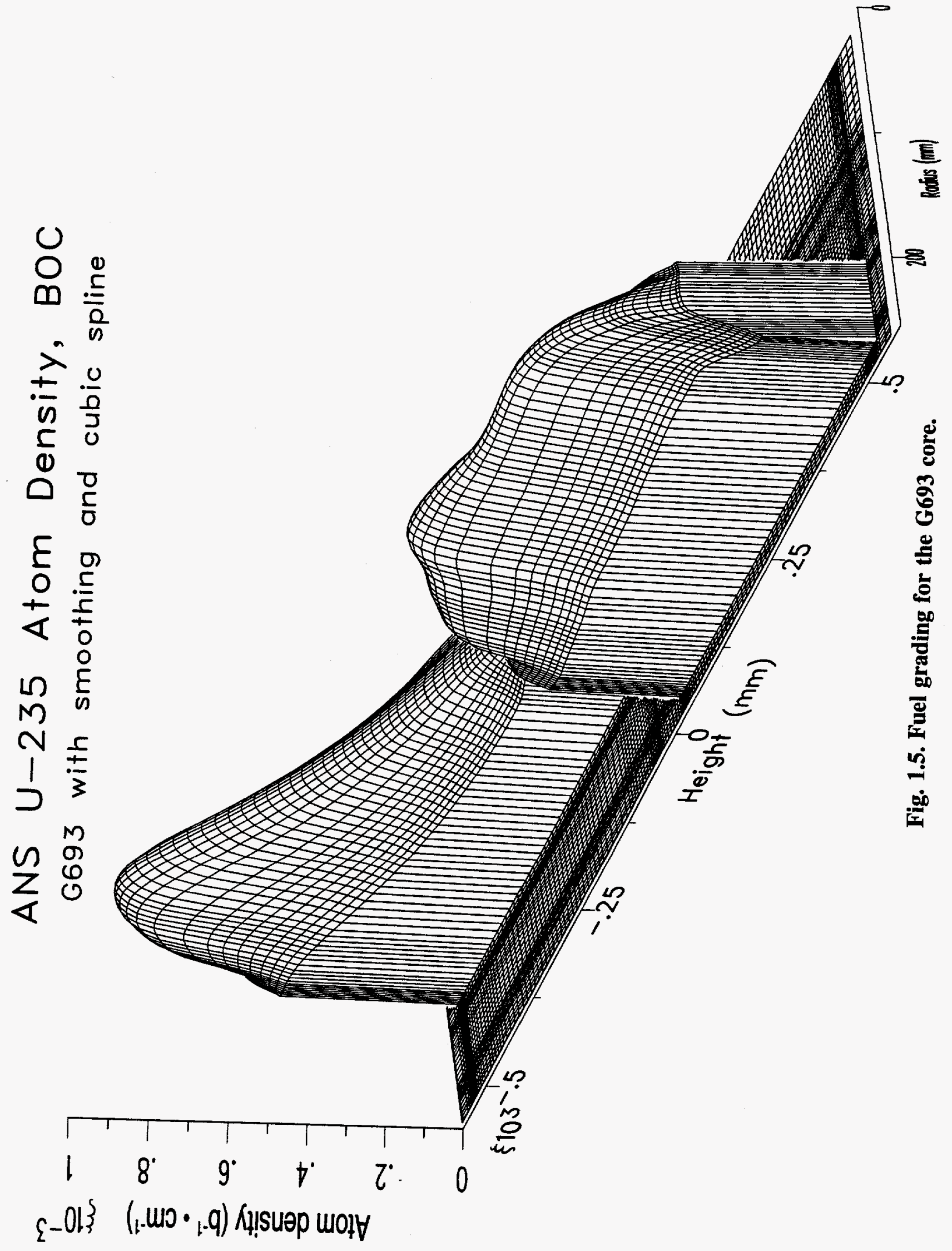


density yields a lower volume fraction of fuel, facilitating fabrication and improving the thermal conductivity and stability of the dispersion. Both $\mathrm{U}_{3} \mathrm{O}_{8}$ and $\mathrm{UAl}_{\mathrm{x}}$ are considered to be viable backup fuels and are being included in the early irradiation tests to obtain performance data at high temperatures and fission rates. Based on existing data, $\mathrm{UAl}_{\mathrm{x}}$ appears to be the most stable of all the prospective fuels in its retention of fission gas. The fuel most easily fabricated to the exacting tolerances of ANS is $\mathrm{U}_{3} \mathrm{O}_{8}$. It retains fission gas well and behaves predictably up to a high level of burnup (perhaps beyond ANS requirements) but undergoes excessive swelling at some point. Fabrication of $\mathrm{U}_{3} \mathrm{Si}_{2}$ is roughly equivalent to that of $\mathrm{UAl}_{\mathrm{x}}$. The existing irradiation behavior data for $\mathrm{U}_{3} \mathrm{Si}_{2}$ show behavior similar to that of the aluminide in that no limits need to be set on burnup; however, unlike the aluminide, the silicide shows some small fission gas bubbles.

The fabrication of ANS fuel elements will be based on the proven methods used for fabrication of the High Flux Isotope Reactor (HFIR) elements. The more exacting requirements of ANS will require some extension of this technology. ANS requires an axial fuel gradient in addition to the radial gradient currently used in HFIR. Because the silicide is a relatively new fuel, the experience base is somewhat limited compared to that with aluminide and oxide. There is some variability in powder properties in regard to fabricability from batch to batch. Like the aluminide, the silicide is somewhat pyrophoric, and glove box handling is required through the compacting process. The ability to handle the oxide powders in air for preparation of the graded compacts is a useful advantage. Thus, a repeatable process for producing large batches of silicide powder is one of the early goals of the fabrication work. Developing a process to passivate this powder so that it can be handled safely in air is also a goal.

The fabrication and performance of ANS fuel is a realistic advancement of existing technology. The projected temperatures and fission rates for ANS are beyond the experience base for any of the research reactor fuels. The primary goal of the irradiation testing program is to validate the performance of the fuel at conditions as close as can be obtained to the temperatures and fission rates of ANS. LEU fuel is now being commercially fabricated with $\mathrm{U}_{3} \mathrm{Si}_{2}-\mathrm{Al}$ dispersions for low- and mediumpowered reactors. The major goal of the fabrication development is to produce plates with a dual-fuel gradient to the more stringent distribution and homogeneity requirements of the ANS.

In February 1992 the ANS fuel development program was reviewed by an outside committee of reactor fuel performance experts. The committee was chaired by R. R. Hobbins of Idaho National Engineering Laboratory and included C. A. Alexander of Battelle Columbus Laboratory and R. D. Leggett of Westinghouse Hanford Company (retired). The committee report ${ }^{4}$ complimented the progress to date, foresaw no insurmountable obstacles in the development of $\mathrm{U}_{3} \mathrm{Si}_{2}$ for the ANS, and said that the choice of fuel was rational. The committee especially commended the degree of interaction between the experimenters in the irradiation test program and the modelers of fuel performance. They also commended the early involvement of the fabricators in the development program. There were five recommendations in the report. The first and second were to formulate rigorous plans presenting the requirements, goals, issues, interfaces, and decision trees for the overall development plan and for the irradiation testing program. This report is in part a response to those recommendations. The third recommendation was to address the burnable poison selection and evaluation sooner rather than later. This has been incorporated into the 
plans as work breakdown structure (WBS) subtask 1.1.2.10, which began in FY 1993. The fourth recommendation was that full-sized plates, or preferably full-sized fuel elements, be irradiated as qualification for ANS fuel. We will begin subtask 1.1.2.9 in FY 1996 to irradiate full-sized plates in the target region of HFIR. This test will provide the closest conditions possible to those of ANS. We are also investigating the feasibility of building and operating a $\mathrm{U}_{3} \mathrm{Si}_{2}-\mathrm{Al}$ core in HFIR (subtask 1.1.2.12). The power and thermal conditions will be those of HFIR. This effort will provide valuable fabrication experience and confidence in the use of $\mathrm{U}_{3} \mathrm{Si}_{2}$ fuel. The fifth recommendation was that the fuel development team interact more closely with the safety analysis and severe accident fuel testing. This recommendation has also been followed as the fuel development staff are taking a more interactive role in the fuel safety testing. Thus, the recommendations of the fuel review committee have been incorporated into the fuel development plan. This report will make the plan more visible and more clearly documented. 


\section{STATUS OF $\mathrm{U}_{3} \mathrm{Si}_{2}$ DEVELOPMENT AT START OF PROJECT}

The U.S. RERTR program was established in 1978 to provide the technical means to convert research and test reactors from the use of highly enriched uranium (HEU) fuel to the use of LEU fuel. ${ }^{5}$ This change required greatly increasing the uranium content to maintain the excess reactivity required for the continued operation of the reactors. To this end, the RERTR program pursued both increasing the volume fraction of existing fuel compounds and developing new higher-density fuel compounds. In 1978, the highest-density fuels in common use in plate-type research reactor fuel elements were dispersions of uranium aluminide (a mixture of $\mathrm{Al}, \mathrm{UAl}_{2}, \mathrm{UAl}_{3}$, and $\mathrm{UAl}_{4}$ phases - usually referred to as $\mathrm{UAl}_{\mathrm{x}}$, where $\mathrm{x} \approx 3$ ) and uranium oxide $\left(\mathrm{U}_{3} \mathrm{O}_{8}\right)$ in aluminum, with fuel meat densities of 1.7 and $1.3 \mathrm{MgU} / \mathrm{m}^{3}$, respectively. These two types of fuels were developed and tested for LEU applications up to their practical fabrication limits of $2.4 \mathrm{MgU} / \mathrm{m}_{3}$ for $\mathrm{UAl}_{\mathrm{x}}$ and $3.2 \mathrm{MgU} / \mathrm{m}^{3}$ for $\mathrm{U}_{3} \mathrm{O}_{8}$. Still higher fuel densities were required for some applications, and higher-density compounds were investigated for these. The compound $\mathrm{U}_{3} \mathrm{Si}_{2}$ was found to perform extremely well during irradiation and could be fabricated successfully at densities up to at least 4.8 $\mathrm{MgU} / \mathrm{m}^{3}$.

The development and testing of $\mathrm{U}_{3} \mathrm{Si}_{2}$ in the United States progressed from miniplates, ${ }^{4}$ to experimental elements, ${ }^{6}$ and to a full demonstration core for the Oak Ridge Research Reactor (ORR). ${ }^{7}$ The demonstration core operated forapproximately 15 months and was fueled by elements from three commercial fabricators: NUKEM, - CERCA, ${ }^{\dagger}$ and $B \& W{ }^{\ddagger}$ This test program ultimately led to approval by the U.S. Nuclear Regulatory Commission of the use of $\mathrm{U}_{3} \mathrm{Si}_{2}$ for the conversion of licensed nonpower reactors from HEU to LEU. ${ }^{2}$ The RERTR program involved international cooperation. Fabrication and testing were done in many countries in addition to the United States. Miniplates, full-sized plates, and/or test elements were fabricated in France, Germany, Argentina, and Indonesia and tested in reactors in France, Germany, Sweden, the Netherlands, Japan, and Indonesia. Some fabrication and testing have been done also in China and in the U.S.S.R.

Summaries of the irradiation experience base for $\mathrm{U}_{3} \mathrm{Si}_{2}$ when the ANS Project began are depicted in Figs. 2.1 and 2.2. This base represents 58 miniplates and 85 elements $(1,587$ full-sized plates), which were carefully evaluated and represent completely satisfactory performance. No plate failures have yet been attributed to the $\mathrm{U}_{3} \mathrm{Si}_{2}-\mathrm{Al}$ fuel dispersion. Figure 2.1 shows fission density in the fuel particles vs uranium density in the meat. Figure 2.2 shows fission density in the meat (combined fuel particles and aluminum matrix) vs uranium density in the meat. Both factors are important in the performance of the fuel during irradiation. The bulk of the data is for high uranium-density loadings of LEU fuel. Thus, the data extend beyond the range expected for ANS in terms of fission density in the meat. (ANS has a low uranium-

-NUKEM Gmbh, Hanau, Federal Republic of Germany.

${ }^{\dagger}$ Compagnie pour l'Etude et la Realization de Combustibles Atomiques, Romans-sur Isere, France.

${ }^{\ddagger}$ Babcock and Wilcox Company, Lynchburg, Va. 


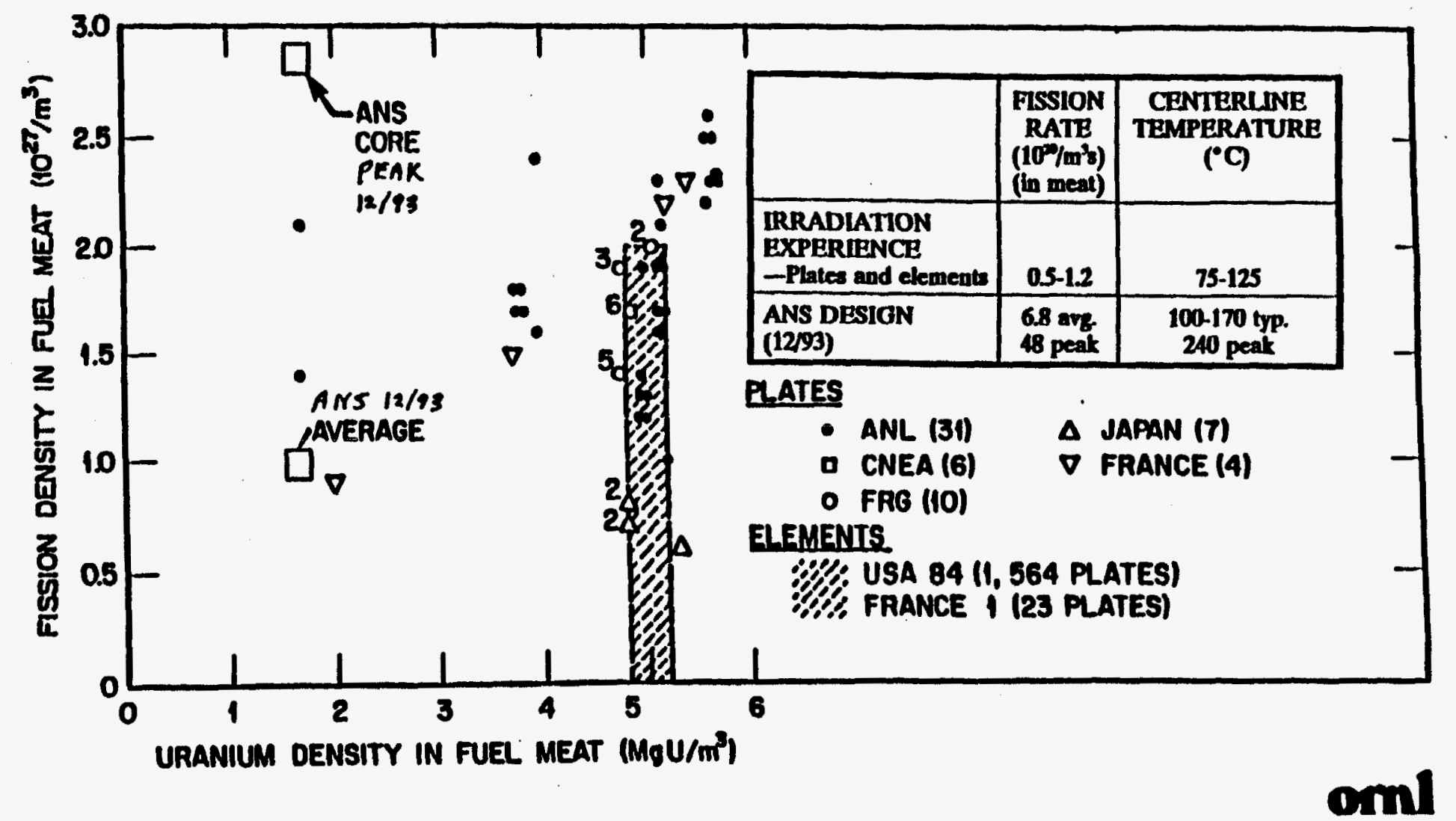

Fig. 2.1. Irradiation experience (fission density in the meat) for $\mathrm{U}_{3} \mathrm{Si}_{2}$ dispersed in aluminum, showing that the data extend almost to the peak fission density in ANS. 


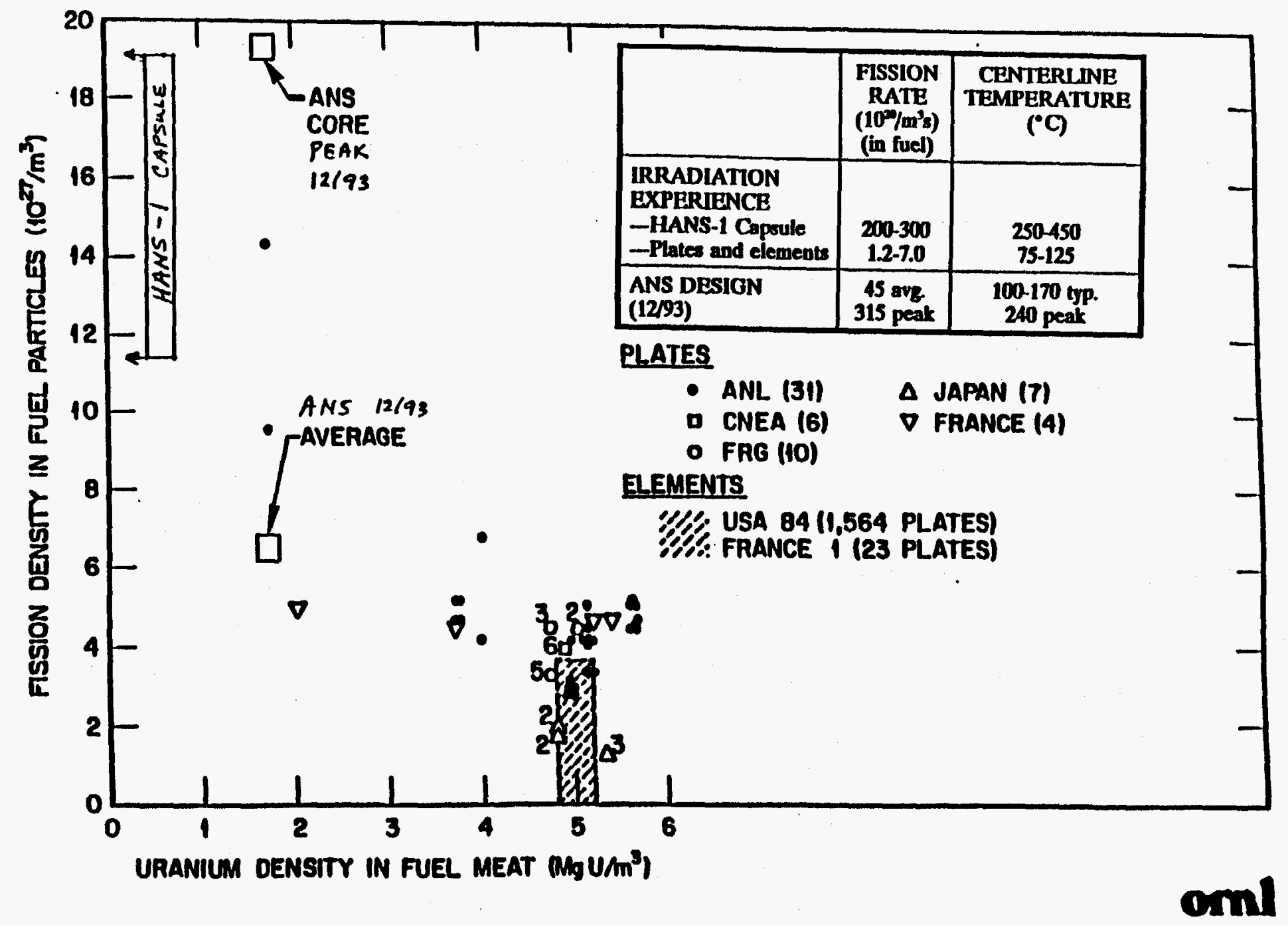

Fig. 2.2. Irradiation experience (fission density in the fuel particles) for $U_{3} \mathrm{Si}_{2}$ dispersed in aluminum, showing that, prior to the HANS-1 capsule, the peak fission density in ANS was outside the experience. 
density loading of HEU fuel). Up to almost $20 \times 10^{27}$ fissions $/ \mathrm{m}^{3}$ in the particle (about 90\% burnup) are expected in ANS in small regions at the edges and ends of the plates where the meat is very thin. The average for the core is about $9 \times 10^{27}$ fissions $/ \mathrm{m}^{3}$. Since the fuel volume fraction is about 0.15 , these values are about 3.0 and $1.4 \times 10^{27}$ fissions $/ \mathrm{m}^{3}$ in the meat.

Only two miniplates of $\mathrm{U}_{3} \mathrm{Si}_{2} \mathrm{HEU}$ have been irradiated to date. These were irradiated by the RERTR program to give some experience well beyond any burnup possible with $\mathrm{LEU}^{4}{ }^{4}$ These plates, with a meat density of $1.66 \mathrm{MgU} / \mathrm{m}^{3}(0.147$ volume fraction), were irradiated in the ORR to burnups of 41 and $69 \%$. This corresponds to 1.4 and $2.3 \times 10^{27}$ fissions $/ \mathrm{m}^{3}$ in the meat and 9.3 and $15.7 \times 10^{27}$ fissions $/ \mathrm{m}^{3}$ in the particles. The plates exhibited good mechanical integrity, and the swelling was somewhat lower than that projected from LEU data. The fuel meat swelling values were 4.9 and $11.6 \%$, and the particle swelling values were 38 and $84 \%$.

Microstructural examination showed the stable structure typical of $\mathrm{U}_{3} \mathrm{Si}_{2}$. As shown in Fig. 2.3, conventional metallography reveals virtually no fission gas bubbles. Higher magnification examination with the scanning electron microscope (SEM) reveals the stable morphology of very small fission gas bubbles shown in Fig. 2.4.

The swelling of $\mathrm{U}_{3} \mathrm{Si}_{2}$ particles of various enrichments as obtained from miniplate data is shown in Fig. 2.5. The amount " $\mathrm{B}$ " is the volume of the bubbles calculated from the microstructure. When the amount " $B$ " is subtracted from the total swelling, the bottom curve (indicated by open circles in Fig. 2.5), representing the swelling in the absence of resolved bubbles, is obtained. The total swelling is lower for higherenrichment fuel that had a higher fission rate. It is hypothesized that this difference is the result of a delay in transition from the lower swelling rate to the higher swelling rate, which corresponds to the formation of fission gas bubbles that can be resolved with SEM (about $40 \mathrm{~nm}$ ). That is, before the knee of the curve, gas bubbles are not observed. Above the knee of the curve (in the higher swelling rate region), gas bubbles are observed with SEM. It is hypothesized that this transition is the result of recrystallization into extremely fine subgrains approximately $500 \mathrm{~nm}$ in diameter, with the gas bubbles precipitating on the subgrain boundaries. ${ }^{8}$

In the fabrication area, the three commercial research reactor fuel suppliers noted above (NUKEM, CERCA, and $\mathrm{B} \& W$ ) were fabricating $\mathrm{U}_{3} \mathrm{Si}_{2}-\mathrm{Al}$ elements for conversion of reactors to $\mathrm{LEU}$ at loadings up to $4.8 \mathrm{MgU} / \mathrm{m}^{3}$ (and experimental elements with loadings up to $5.2 \mathrm{MgU} / \mathrm{m}^{3}$ ). Test elements were in several reactors, and several reactors were in the process of converting to the silicide LEU fuel. The fabrication problems included homogeneity and reproducibility, uniformity of meat thickness for the high-loaded plates, flaking of fuel particles (fuel particles in the edge and end cladding), and oxidation (burning) of fuel on the compact surfaces, resulting in unsatisfactory bonding. Many of these problems (such as uniformity of meat thickness, flaking, and burning) will be minimized or eliminated in the ANS simply by the low volume fraction of fuel needed. Homogeneity and reproducibility will remain as potential problems or possibly be accentuated by the low volume fraction and will require development work. The production of reproducible dual-fuel gradients will require development work as well. 


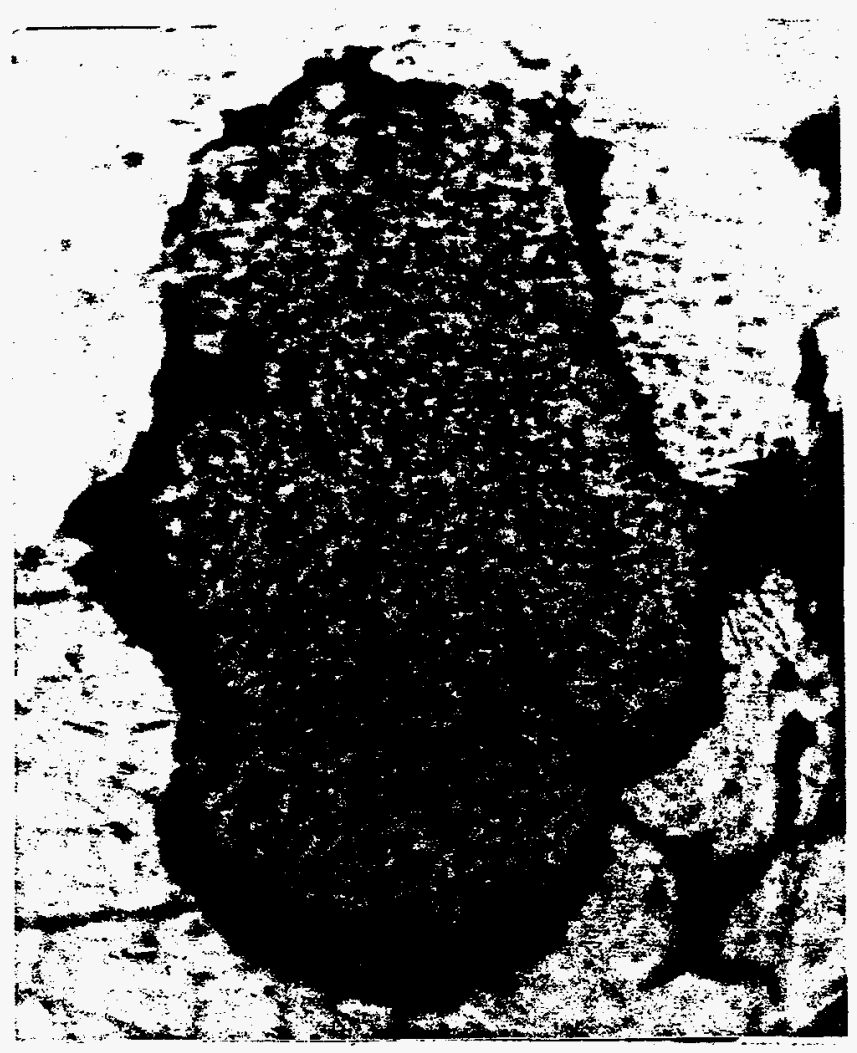

HFIR HEU, $90 \%$ burnup, $2 \times 10^{22}$ fissions $\mathrm{m}^{-3} \cdot \mathrm{s}^{-1}$

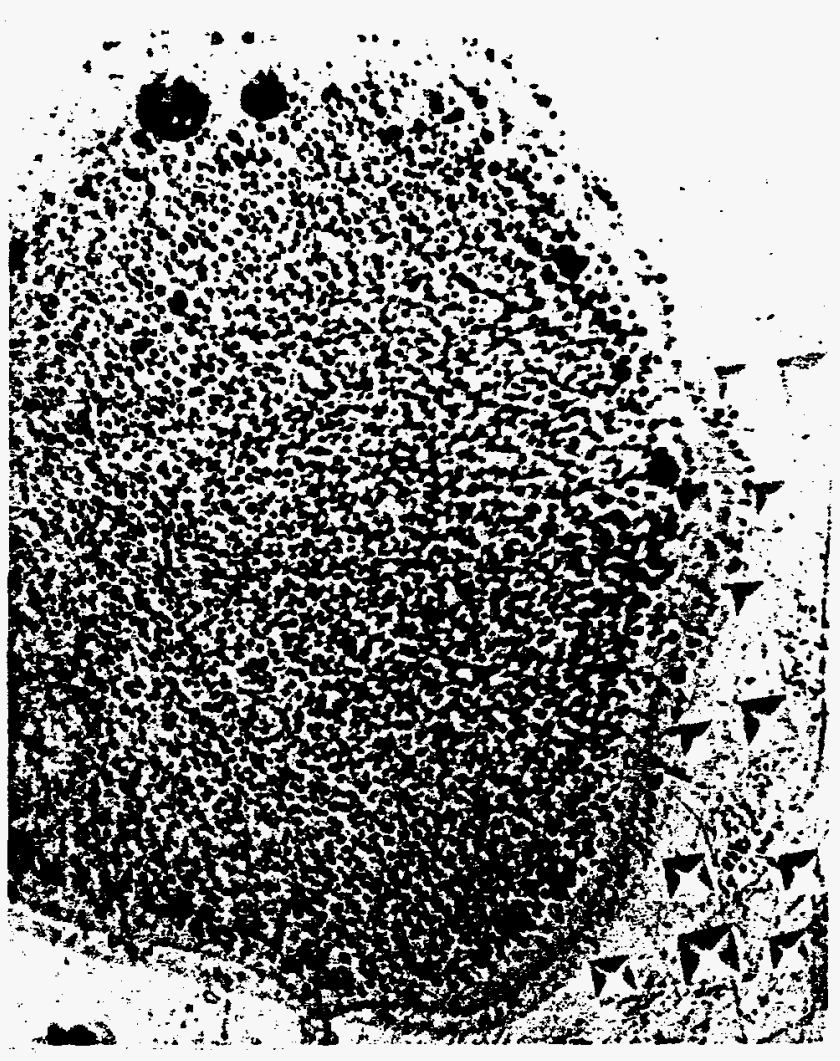

ORR HEU, $70 \%$ burnup, $7 \times 10^{20}$ fissions $\mathrm{m}^{-3} \cdot \mathrm{s}^{-1}$

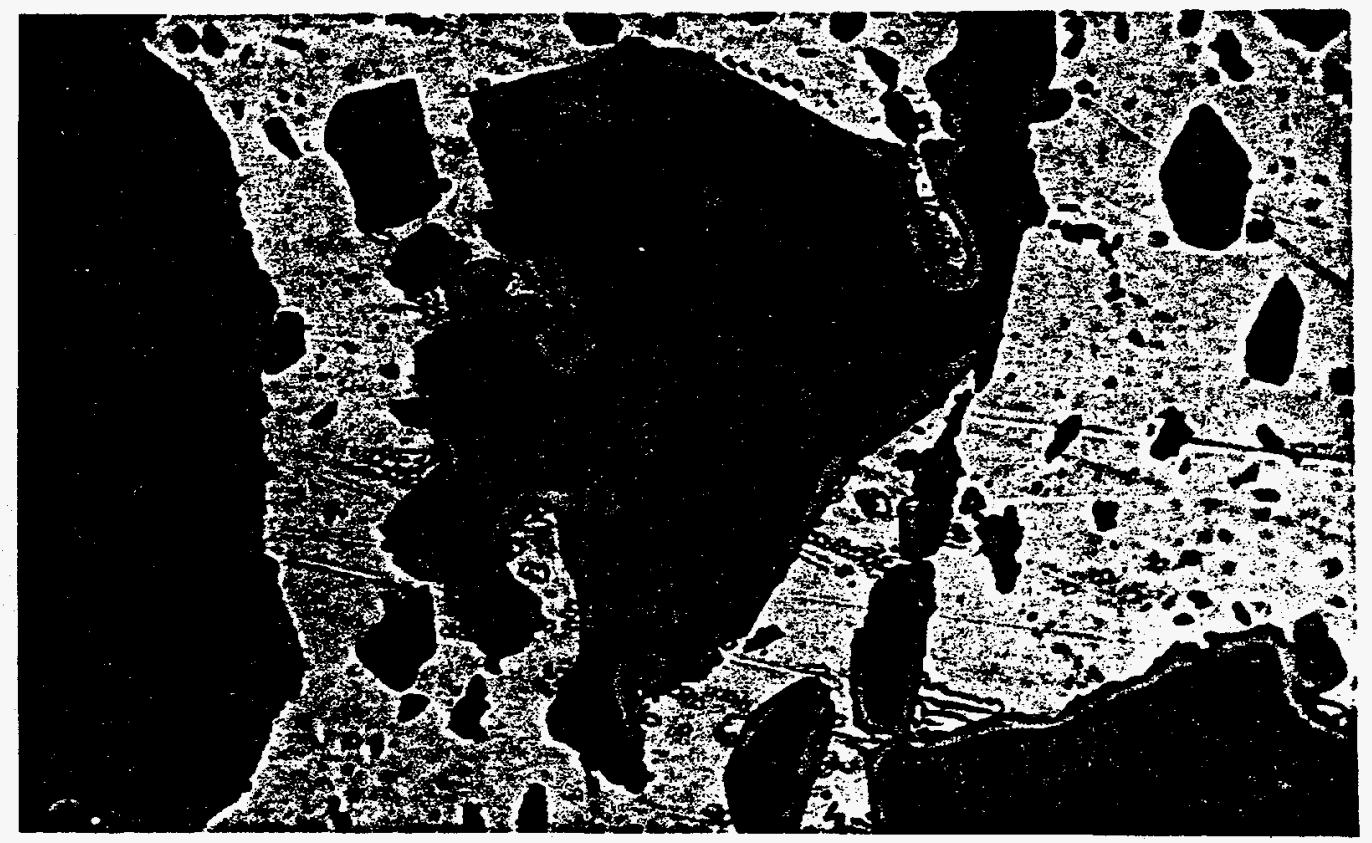

ORR LEU, $90 \%$ burnup, $2 \times 10^{20}$ fission $\mathrm{m}^{-3} \cdot \mathrm{s}^{-1}$

Fig. 2.3. Comparison of postirradiation microstructure of $\mathrm{U}_{3} \mathrm{Si}_{2}$ HEU irradiated in HFIR vs HEU and LEU irradiated in ORR ( 500 X). 

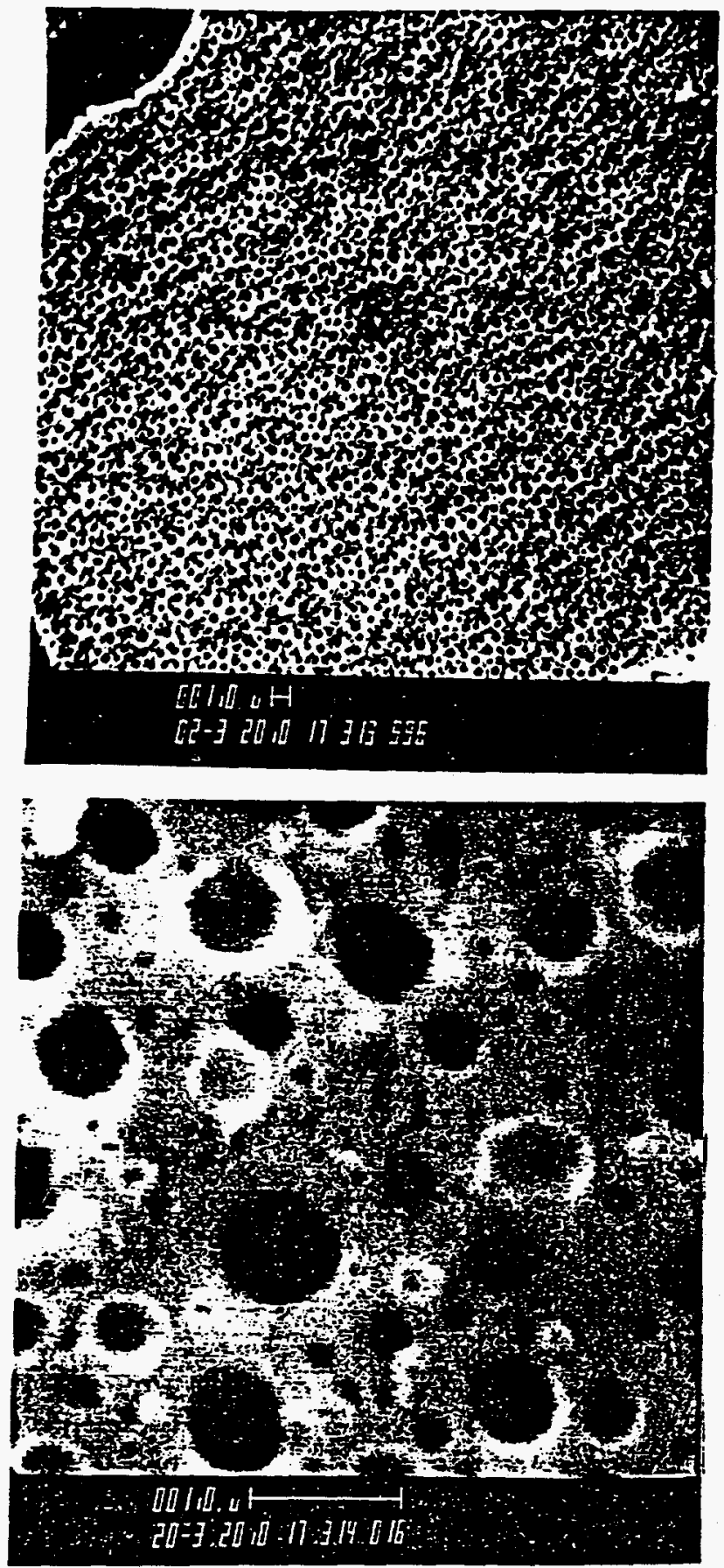

HEU at $9.5 \times 10^{27}$ fissions $/ \mathrm{m}^{3}$
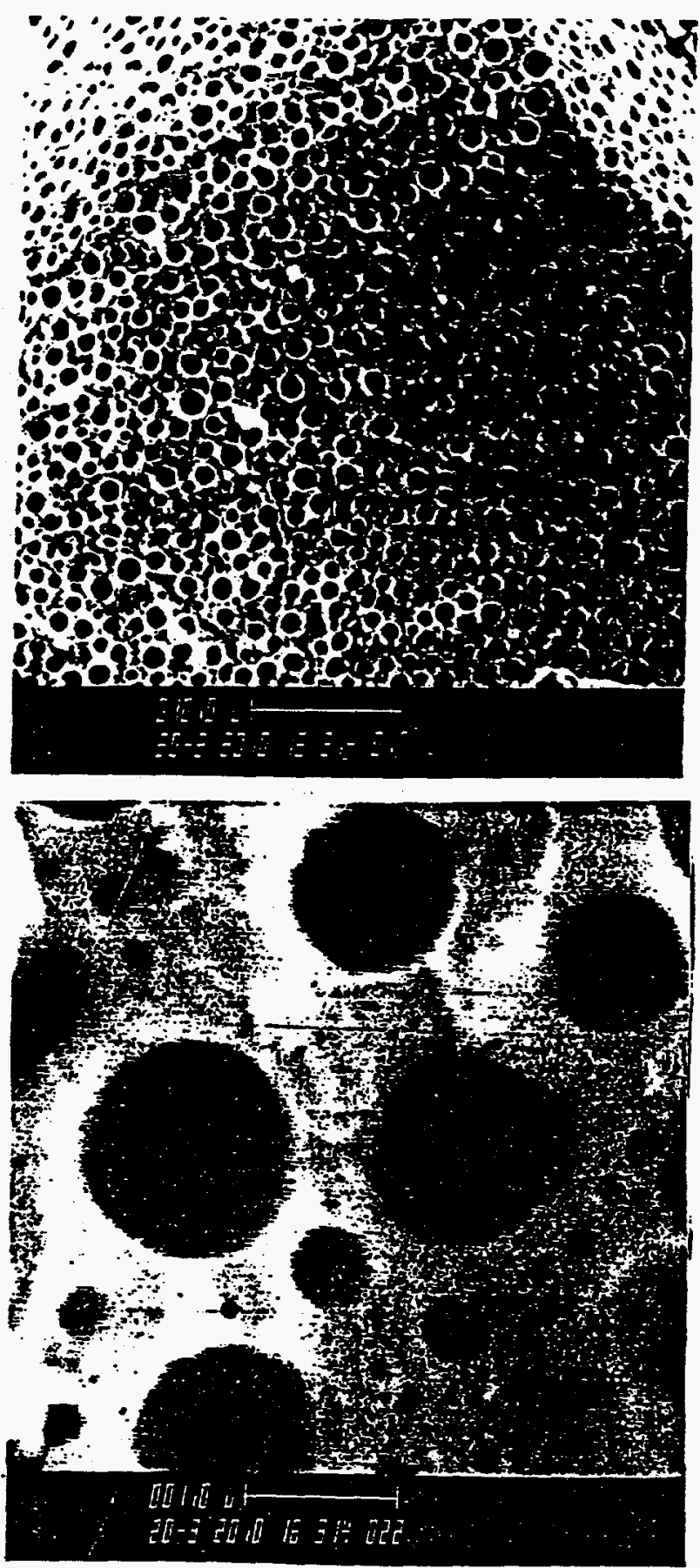

HEU at $14 \times 10^{27}$ fissions $/ \mathrm{m}^{3}$

Fig. 2.4. Scanning electron microscopy reveals a stable gas bubble distribution in HEU plates irradiated in ORR. 




Fig. 2.5. Fuel particle swelling obtained from $\mathrm{U}_{3} \mathrm{Si}_{2}-\mathrm{Al}$ miniplates of various enrichments. 


\section{QUALIFICATION OF FUEL FOR THE ANTICIPATED OPERATING CONDITIONS OF THE ADVANCED NEUTRON SOURCE REACTOR}

The fuel development task has to meet essentially two requirements to qualify fuel for use in the ANS. The first is that the design requirements as specified by the neutronic and thermal-hydraulics analyses must be consistent with ANS's ability to fabricate the fuel. The second is to verify that the element will perform satisfactorily under the operating conditions of the reactor, from off-normal conditions to those of anticipated events (after which continued use of the element is planned).

\subsection{FABRICATION}

The ANS core configuration is very similar to that of the HFIR, with the outer and inner elements separated axially as well as radially. Thus, the processes for making plates of this configuration and assembling them into elements is well established. Development and qualification of the processes and products are needed in those areas that depart from HFIR technology: fuel distribution, the use of $\mathrm{U}_{3} \mathrm{Si}_{2}$ rather than $\mathrm{U}_{3} \mathrm{O}_{8}$, and more strict requirements on fuel homogeneity and distribution and bonding of meat to cladding. Figure 3.1 is the logic diagram for qualifying the fabrication of fuel to the ANS requirements.

\subsubsection{Fuel Distribution}

The specified ANS operating conditions require that the fuel be graded in both the axial and radial the directions, whereas HFIR fuel is graded only in the radial direction. It is also desirable that the meat be centered in the thickness of the plate. These specifications require modification of the HFIR process. The homogeneity requirements are more stringent than those of HFIR in that the uranium content of a 2$\mathrm{mm}$-diam spot is to be $\pm 20 \%$ rather than $\pm 27 \%$ of that specified, and in that the average of a 2 - by 12 -mm streak is to be $\pm 10 \%$ rather than $\pm 12 \%$ of the nominal. These requirements may necessitate both process and inspection improvements to ensure that the fuel meets the specifications.

To date, we have demonstrated the feasibility of producing dual-fuel gradients with a modification of the HFIR fabrication process. The reproducibility of the process has yet to be demonstrated. The method used has the desirable tendency to place the thin portions of the meat near the center of the plate thickness.

\subsubsection{Change from Oxide to Silicide Fuel Particles}

The use of silicide rather than oxide fuel raises several issues that must be addressed in a development program. The silicide fuel particles are about $50 \%$ more dense than the oxide particles and have a different surface character. These differences raise the question of whether the blending with aluminum powder can ever be as good 


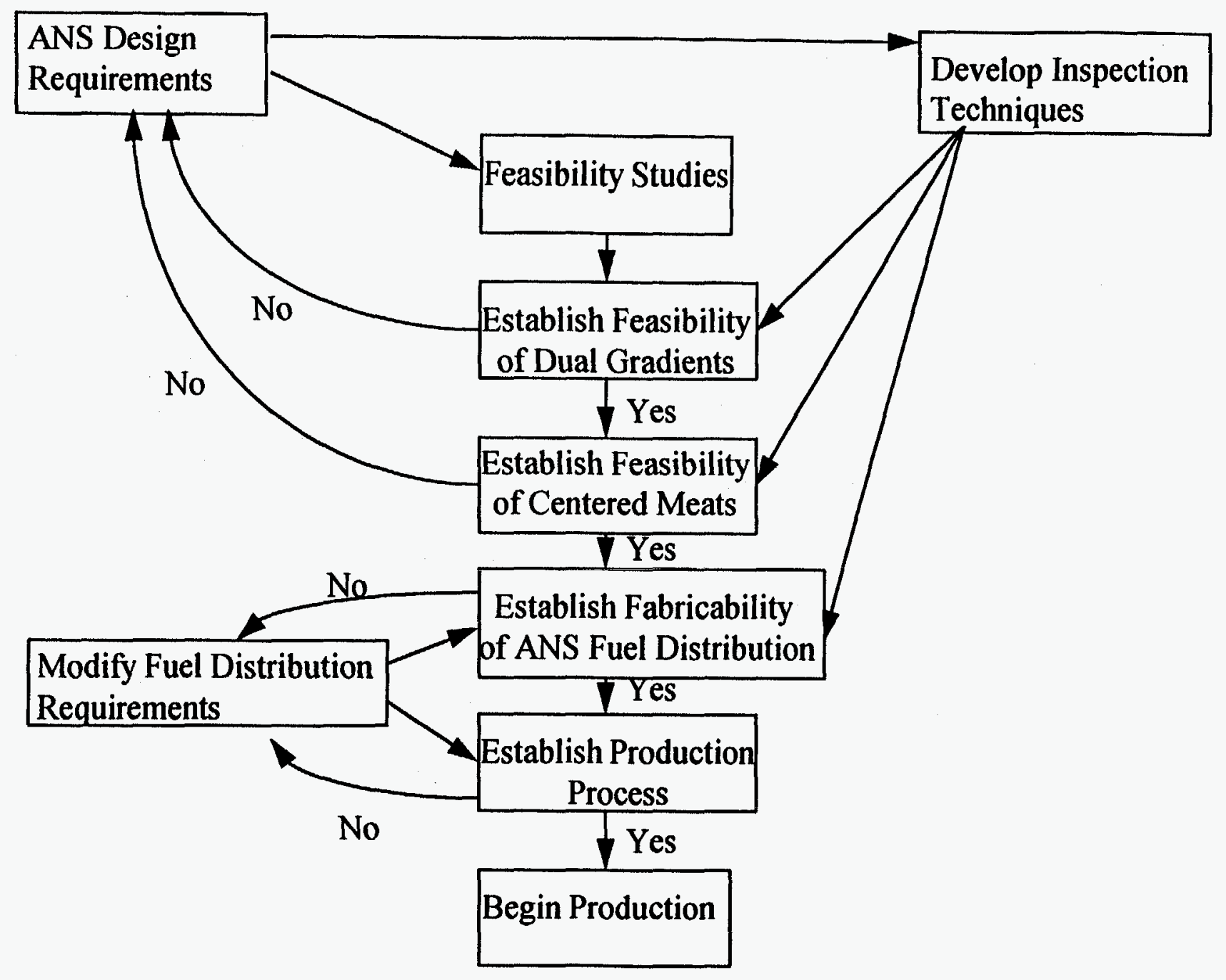

Fig. 3.1. Logic diagram for qualification of the fuel fabrication for ANS. 
as that obtained with oxide. The silicide powder is somewhat pyrophoric and must be handled in inert-atmosphere glove boxes through the compacting step. This constraint hinders the accessibility of the dies and complicates the compacting process, which in any case requires a high level of operator skill and training to achieve the graded compacts. The pyrophoric nature of the silicide powder also complicates the heating of the billet assemblies prior to roll bonding because the reaction of the surface particles with air sometimes inhibits bonding to the cladding. The low volume fraction of the ANS plates will be a help in this case, but some process improvements may be required to ensure reliable bonding. Another issue is that the production process for silicide powder is inherently a small-batch process. Some development will be required either to ensure uniform batch properties or to devise a cross-blending technique for large batches.

Plates identical to the HFIR outer element plates have been made, with $\mathrm{U}_{3} \mathrm{Si}_{2}$ substituted for $\mathrm{U}_{3} \mathrm{O}_{8}$ and fuel density increased from 1.25 to $1.35 \mathrm{MgU} / \mathrm{m}^{3}$. These plates had standard deviations of fuel distribution identical to those of the HFIR oxide plates, showing that there is no inherent inability to achieve good fuel distribution with the silicide fuel powder. Subsequent changes in fuel powder size and control of aluminum powder characteristics have improved the fuel distribution markedly in $\mathrm{U}_{3} \mathrm{Si}_{2}$ development plates. Thus, the planned improvement in fuel distribution over HFIR appears to be a feasible and reasonable goal.

\subsubsection{Inspection Technology}

The inspections to the levels required are within the state of the art. However, the inspection techniques and equipment currently in use will require upgrading to ensure that the elements meet the specification requirements. The $\mathrm{x}$-ray homogeneity scanner has already been upgraded from analog comparison to computer control and digital data acquisition. This change was required simply by the nonuniform axial loading needed in the ANS plates; however, digital data acquisition gives quantitative data on fuel distribution that greatly improves the ability to study the effects of process variables on fuel distribution and may allow more meaningful specification of homogeneity requirements. The $x$-ray scanner retains the same power and spot size as previously. Investigation continues on further improvements in the technology that may reduce the uncertainties now inherent in the fuel distribution. Ultrasonic equipment exists to inspect nonbonds to the $1-\mathrm{mm}$-diam level rather than the 2-mmdiam level used for HFIR.

\subsection{IRRADIATION PERFORMANCE}

The operating conditions of ANS are outside the experience base for any of the research reactor fuels. Irradiation testing to verify the performance under ANS conditions is therefore required. It may be impossible to duplicate all parameters of the ANS conditions exactly and simultaneously because ANS is explicitly designed to exceed the performance of any existing research reactor. Consequently, testing under various conditions that approach those of ANS will be required to validate a fuel performance model. The estimated fuel conditions in the ANS based on the conceptual design core and updated by the additional fuel loading up to $1.7 \mathrm{MgU} / \mathrm{m}^{3}$ are as follows: 
Peak thermal flux in fuel, $10^{19} \mathrm{~m}^{-2} \cdot \mathrm{s}^{-1}$

$\begin{array}{ll}\text { Peak fast flux, } 10^{19} \mathrm{~m}^{-2} \cdot \mathrm{s}^{-1} & 2 \\ \text { Temperature, }{ }^{\circ} \mathrm{C} & \\ \text { Typical } & 100-170 \\ \text { Maximum centerline } & 240 \\ \text { Hot spot }^{*} & 400\end{array}$

Fission density in fuel, $10^{27} / \mathrm{m}^{3}$

Peak

Average

Fission density in meat, $10^{27} / \mathrm{m} 3$

Peak

Average

Fission rate, $10^{20}$ fissions $\mathrm{m}^{-3} \cdot \mathrm{s}^{-1}$

Peak

Average

These values may change as the core design evolves. The peak values, for instance, are very sensitive to the fuel grading, and improved gradings will probably lower the power peaking. The test matrix for the miniplate tests will be based on the latest core design and will make some allowances for continuing design evolution.

Since no existing irradiation facility has the capability to irradiate prototype ANS fuel under prototypic ANS conditions, a fuel performance model must be used to predict fuel performance at or beyond ANS conditions. This mechanistic model, which is being developed based on the body of existing irradiation data for the $\mathrm{U}_{3} \mathrm{Si}_{2}-\mathrm{Al}$ system, will be continually tested and updated by a series of irradiation tests and irradiation damage simulations (by ion and neutron bombardment at very high dose rates). The irradiation damage simulations consist of small samples bombarded by krypton ions in the electron microscope and by neutrons in the Intense Pulsed Neutron Source at ANL. The model will be validated by irradiation tests conducted in conditions as close as possible those of ANS.

Several types of irradiation tests are planned to qualify the ANS fuel for use in the reactor. These will test the extremes of the conditions expected and validate the fuel performance model for use in combining the various test results. Figure 3.2 is the logic diagram for the fuel performance qualification.

*This is the temperature of a very small region (about $0.3-\mathrm{mm}$ diam) resulting from combining the worst allowable fuel segregation spot with the largest nondetectable nonbond at the worst time in the reactor cycle and the worst place in the reactor core. Based on the current irradiation test results, even higher temperatures may prove to be allowable for such miniscule regions. 




Fig. 3.2. Logic diagram for qualification of the fuel performance for ANS. 


\subsubsection{Capsule Tests in the High Flux Isotope Reactor Target}

The capsule irradiation tests are to determine the irradiation behavior of fuel samples under temperatures and burnup rates approaching the maximums expected in ANS. Extremely small samples are being tested in the target region of HFIR, where the burnup rates will be high. In fact, the thermal flux and fission rates approximate the peaks expected in ANS. The peak thermal flux in the HFIR target is about $2.4 \times 10^{19} \mathrm{~m}^{-2} \cdot \mathrm{s}^{-1}$, and the resulting fission rate is up to about $300 \times 10^{20} \mathrm{~m}^{-3} \cdot \mathrm{s}^{-1}$. The desired temperature will be attained mainly from gamma heating in the capsule and a gas gap to limit heat conduction. The small sample size keeps the fission heat contribution small in comparison to the gamma heat, so temperatures stay relatively constant during the test.

Three capsule tests are included in the program. The test matrices for the first two tests are shown in Table 3.1, and the test matrix for the third capsule is shown in Table 3.2. The first capsule test has been irradiated, and postirradiation examination is complete. The capsule specimens consisted primarily of the prime candidate fuel at various temperatures and burnup rates ( 4 of the 36 specimens were $\mathrm{U}_{3} \mathrm{Si}$ ). The second capsule test has been irradiated, and postirradiation examination is in progress. It consists of the backup fuels $\mathrm{U}_{3} \mathrm{O}_{8}$ and $\mathrm{UAl}_{\mathrm{x}}$ and the prime fuel $\mathrm{U}_{3} \mathrm{Si}_{2}$ under conditions as representative as possible of the extremes in ANS. The tests contain passive temperature monitors. The third capsule test will contain a combination of the three fuels irradiated under various conditions, with an important difference in specimen preparation. The specimens in the third test are small punchings of dispersion meats from hot-rolled plates rather than lightly compacted powder blends. This method will make the thermal and chemical conditions of the test fuel particles typical of those in the reactor fuel. The primary evaluation in all three tests is microstructural (SEM) to evaluate the compatibility of the fuel and matrix and the ability to retain fission gas in a stable bubble configuration. The fission gas bubble size distributions will be used with the fuel performance model to predict particle swelling rates and overall fuel performance.

The results of the first capsule test show that the fuel particles exhibit predictable swelling under the peak conditions expected in ANS, even though swelling is substantially higher than was experienced in the previous low-fission rate, low-temperature irradiation tests. After essentially full burnup under these extreme conditions, the fuel particles exhibit three zones, which appear to be as follows: the outermost periphery is a reaction zone consisting of a $\mathrm{U}(\mathrm{Si}, \mathrm{Al})_{3}$ structure, which converted to aluminide before recrystallization and has only extremely small, stable fission-gas bubbles; the second zone has undergone recrystallization of the $\mathrm{U}_{3} \mathrm{Si}_{2}$ structure before converting to the aluminide structure and contains small, stable gas bubbles; larger bubbles occur in the innermost amorphous zone, where the uranium has been depleted to the point that a more unstable silicon compound is formed before aluminum diffusion or recrystallization could stabilize the bubble morphology. This structure and the corresponding bubble distributions as calculated by the fuel performance model are shown in Fig. 3.3. The overall particle swelling of the high-burnup particles is higher than that experienced for $\mathrm{U}_{3} \mathrm{Si}_{2}$ under less extreme irradiation conditions. This amount of swelling is not a problem for ANS, especially because the extremes of burnup occur only in regions where the meat is very thin. The potential for extreme or "breakaway" swelling appears to be minimal because the larger bubble region is constrained by the stable outermost regions of the particle. The ANS will reach these extremes of burnup in only a small percentage of the fuel at the periphery of the fuel plates, where the meat is thin. Particles of lower burnup typical of the bulk of the ANS fuel do not exhibit the inner core of larger bubbles. 
Table 3.1. Comparison of fuel holder characteristics by position in capsules HANS-1 and HANS-2

\begin{tabular}{|c|c|c|c|c|c|}
\hline \multirow{2}{*}{$\begin{array}{l}\text { Capsule } \\
\text { position } \\
\text { number }\end{array}$} & \multicolumn{2}{|c|}{ HANS-1 } & \multicolumn{3}{|c|}{ HANS-2 } \\
\hline & $\begin{array}{l}\text { Fuel } \\
\text { type }\end{array}$ & $\begin{array}{c}\text { Design } \\
\text { temperature }\left({ }^{\circ} \mathrm{C}\right)\end{array}$ & $\begin{array}{l}\text { Fuel } \\
\text { type }\end{array}$ & $\begin{array}{c}\text { Design } \\
\text { temperature }\left({ }^{\circ} \mathrm{C}\right)\end{array}$ & $\begin{array}{c}\text { Melt } \\
\text { monitors }\end{array}$ \\
\hline 1 & $\mathrm{U}_{3} \mathrm{Si}_{2}$ & 425 & $\mathrm{U}_{3} \mathrm{O}_{8}$ & 425 & \\
\hline 2 & $\mathrm{U}_{3} \mathrm{Si}_{2}$ & 375 & $\mathrm{UAl}_{2}$ & 425 & $\mathrm{Bi}, \mathrm{Pb}, \mathrm{Zn}$ \\
\hline 3 & $\mathrm{U}_{3} \mathrm{Si}_{2}$ & 325 & $\mathrm{U}_{3} \mathrm{O}_{8}$ & 250 & \\
\hline 4 & $\mathrm{U}_{3} \mathrm{Si}_{2}$ & 250 & $\mathrm{UAl}_{2}$ & 250 & $\mathrm{Sn}, \mathrm{Pb}-\mathrm{Sb}, \mathrm{Bi}$ \\
\hline 5 & $\mathrm{U}_{3} \mathrm{Si}_{2}$ & $<250$ & $\mathrm{U}_{3} \mathrm{O}_{8}$ & 325 & $\mathrm{~Pb}-\mathrm{Sb}, \mathrm{Bi}, \mathrm{Pb}$ \\
\hline 6 & $\mathrm{U}_{3} \mathrm{Si}_{2}$ & 250 & $\mathrm{UAl}_{2}$ & 375 & \\
\hline 7 & $\mathrm{U}_{3} \mathrm{Si}_{2}$ & 325 & $\mathrm{U}_{3} \mathrm{O}_{8}$ & 375 & $\mathrm{Bi}, \mathrm{Pb}, \mathrm{Zn}$ \\
\hline 8 & $\mathrm{U}_{3} \mathrm{Si}_{2}$ & 375 & $\mathrm{UAl}_{2}$ & 425 & \\
\hline 9 & $\mathrm{U}_{3} \mathrm{Si}_{2}$ & 425 & $\mathrm{U}_{3} \mathrm{O}_{8}$ & 425 & $\mathrm{Bi}, \mathrm{Pb}, \mathrm{Zn}$ \\
\hline 10 & $\mathrm{U}_{3} \mathrm{Si}_{2}$ & 425 & $\mathrm{UAl}_{\mathrm{x}}$ & 425 & \\
\hline 11 & $\mathrm{U}_{3} \mathrm{Si}_{2}$ & 375 & $\mathrm{U}_{3} \mathrm{Si}_{2}$ & 425 & \\
\hline 12 & $\mathrm{U}_{3} \mathrm{Si}_{2}$ & 325 & $\mathrm{UAl}_{\mathrm{x}}$ & 375 & \\
\hline 13 & $\mathrm{U}_{3} \mathrm{Si}_{2}$ & 250 & $\mathrm{U}_{3} \mathrm{Si}_{2}$ & 375 & \\
\hline 14 & $\mathrm{U}_{3} \mathrm{Si}_{2}$ & 375 & $\mathrm{U}_{3} \mathrm{Si}_{2}$ & 325 & \\
\hline 15 & $\mathrm{U}_{3} \mathrm{Si}_{2}$ & 425 & $\mathrm{UAl}_{\mathrm{x}}$ & 250 & \\
\hline 16 & $\mathrm{U}_{3} \mathrm{Si}_{2}$ & 375 & $\mathrm{U}_{3} \mathrm{Si}_{2}$ & 250 & \\
\hline 17 & $\mathrm{U}_{3} \mathrm{Si}_{2}$ & 325 & $\mathrm{UAl}_{\mathrm{x}}$ & 425 & \\
\hline 18 & $\mathrm{U}_{3} \mathrm{Si}_{2}$ & 250 & $\mathrm{U}_{3} \mathrm{Si}_{2}$ & 425 & \\
\hline
\end{tabular}

Melting temperatures $\left({ }^{\circ} \mathrm{C}\right)$ of monitor materials: $\mathrm{Sn}, 232 ; \mathrm{Pb}-\mathrm{Sb}, 247 ; \mathrm{Bi}, 271 ; \mathrm{Pb}, 327$; and $\mathrm{Zn}, 420$. 
Table 3.2. Test matrix for HANS-3

\begin{tabular}{|c|c|c|c|}
\hline Position & Fuel & $\begin{array}{c}\text { Enrichment } \\
(\%)\end{array}$ & $\begin{array}{c}\text { Temperature } \\
\left({ }^{\circ} \mathrm{C}\right)\end{array}$ \\
\hline 1 & $\mathrm{U}_{3} \mathrm{Si}_{2}$ & 93.0 & $<200$ \\
\hline 2 & $\mathrm{U}_{3} \mathrm{Si}$ & 92.6 & $<200$ \\
\hline 3 & $\mathrm{U}_{3} \mathrm{Si}$ & 92.6 & 250 \\
\hline 4 & $\mathrm{U}_{3} \mathrm{Si}_{2}$ & 40.1 & 425 \\
\hline 5 & $\mathrm{U}_{3} \mathrm{O}_{8}$ & 93.2 & 250 \\
\hline 6 & $\mathrm{U}_{3} \mathrm{Si}$ & 92.6 & 250 \\
\hline 7 & $\mathrm{U}_{3} \mathrm{O}_{8}$ & 93.2 & 425 \\
\hline 8 & $\mathrm{U}_{3} \mathrm{Si}_{2}$ & 93.0 & 425 \\
\hline 9 & $\mathrm{U}_{3} \mathrm{Si}_{2}$ & 93.0 & 250 \\
\hline 10 & $\mathrm{U}_{3} \mathrm{Si}_{2}$ & 19.8 & 250 \\
\hline 11 & $\mathrm{U}_{3} \mathrm{Si}_{2}$ & 19.8 & 425 \\
\hline 12 & $\mathrm{UAl}_{2}$ & 93.1 & 425 \\
\hline 13 & $\mathrm{UAl}_{2}$ & 93.1 & 250 \\
\hline 14 & $\mathrm{U}_{3} \mathrm{Si}_{2}$ & 93.0 & 250 \\
\hline 15 & $\mathrm{U}_{3} \mathrm{Si}_{2}$ & 40.1 & 425 \\
\hline 16 & $\mathrm{U}_{3} \mathrm{Si}_{2}$ & 93.0 & 425 \\
\hline 17 & $\mathrm{U}_{3} \mathrm{Si}_{2}$ & 19.8 & 425 \\
\hline 18 & $\mathrm{U}_{3} \mathrm{Si}_{2}$ & 19.8 & 250 \\
\hline
\end{tabular}



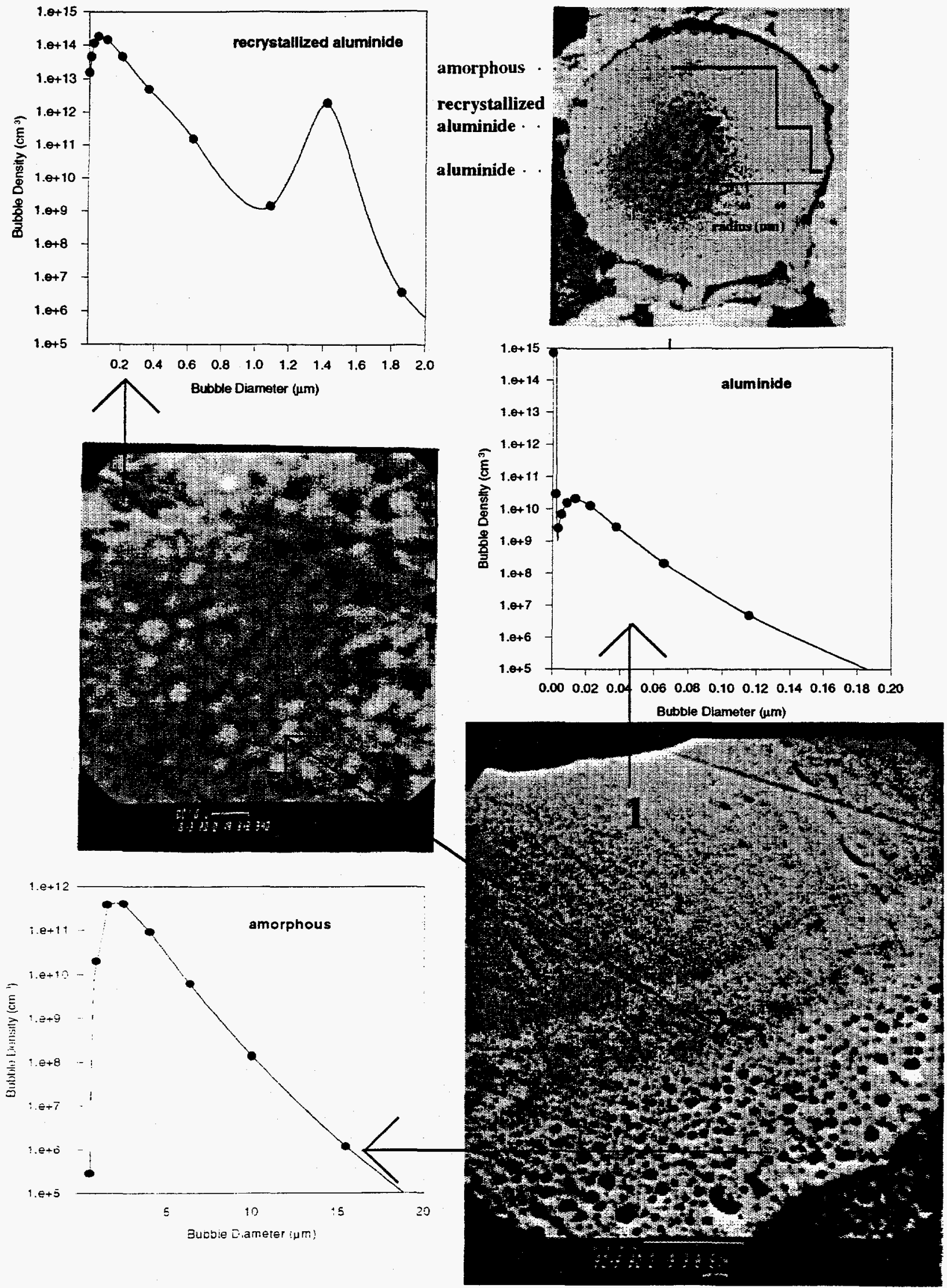

Fig. 3.3. Microstructure of the high-burnup $\mathrm{U}_{3} \mathrm{Si}_{2} \mathrm{HEU}$ particles from the HANS-1 capsule and the fuel performance model calculation of the fission gas bubble distributions. 


\subsubsection{Miniplate Irradiation Tests}

The fuel capsule irradiations provide much useful information about the behavior of the fuel, but miniplates are preferred for accurate fuel swelling data and postirradiation heating tests. Therefore, to determine structural stability, plates typical of the ANS must be irradiated to beyond the burnup levels actually expected.

These tests, under irradiation to burnups typical of ANS, are to measure both plate swelling and interactions between fuel and matrix, fuel and burnable poison, burnable poison and matrix, and meat and cladding. The test matrix has not yet been established. The current proposal is a series of miniplate tests in the target region of HFIR, where the neutron flux conditions approximate those of the ANS fuel. The preliminary mechanical, thermal, and neutronic design (scheduled in FY 1995) must be completed prior to formalizing the test matrix. It is expected that the surface heat flux must be limited to much less than that of ANS. If so, prototypic fuel loadings cannot be tested, and areal ${ }^{235} \mathrm{U}$ loadings will have to be limited by thinning the meat, lowering the volume fraction, lowering the enrichment level, or some combinations of these three methods. Once the test limitations are established, a test matrix will be designed to validate the fuel performance model and then, in conjunction with the model, used to qualify the fuel for ANS conditions. The plates will be evaluated for general condition, swelling, microstructural stability, fission product retention, and stability during postirradiation heating.

\subsubsection{Full-Sized Plate Irradiation}

Although the capsule and miniplate tests supply a good data base on the performance of the fuel under irradiation, some review committees have indicated that irradiations of fullsized plates should provide a final verification of satisfactory performance. The testing of fullsized plates will ensure that no warping or bowing occurs because of burnup or temperature variations. In addition, the full-sized plate irradiations will provide a final validation of the fuel performance models.

This task is to verify the satisfactory irradiation performance of full-sized ANS plates in conditions as near to prototypic as possible. The tests are planned for the target region of HFIR and will consist of a module of several plates with prototypic spacing. Evaluations of the fuel capsule and fuel miniplate tests will be performed before final fabrication of the fullsized plate test.

\subsubsection{Irradiation of Experimental $\mathrm{U}_{3} \mathrm{Si}_{2}$ Element in High Flux Isotope Reactor}

Fabrication of a HFIR element with $\mathrm{U}_{3} \mathrm{Si}_{2}$ plates will provide additional fabrication experience with the relatively new fuel, and the satisfactory operation of the element in a high-performance reactor such as HFIR will provide added confidence for the performance in ANS.

The experimental $\mathrm{U}_{3} \mathrm{Si}_{2}$ element to be operated in HFIR will operate at the standard HFIR power and flow conditions. The element will be loaded with additional uranium and burnable poison, if possible, to extend the core life. The element will then serve a dual purpose as a demonstration for ANS and for an extended-life HFIR element. The ANS Project will pay for the necessary safety assessments and documentation changes to make it possible to operate the experimental core. HFIR will pay for the actual fabrication of the element and 
its operation. The ANS Project will then perform the limited postirradiation examination to verify satisfactory performance.

\subsubsection{Burnable Poison Selection and Testing}

This task provides the evaluations and testing necessary to select the burnable poison for ANS and to verify its satisfactory performance in the fuel plates. Based on its satisfactory performance in HFIR, boron carbide is the burnable poison included in the ANS conceptual design. However, technical staff evaluations and fuel review committee comments indicate that helium production, which lowers the resistance to blistering in postirradiation heating tests, may affect the structural performance of the plate. Poisons that generate no gas or release less gas may offer additional margin. Consequently, alternative burnable poisons will be examined with respect to their compatibility with the fuel and cladding.

The selection and testing task includes out-of-pile compatibility testing and fabrication feasibility testing for poison materials that have been selected based on neutronic desirability. The selected materials will be included in at least some of the miniplates and full-sized plates in the irradiation test program discussed earlier.

\subsubsection{Off-Normal Fuel and Operation}

The test matrix for the miniplate irradiations will address performance of fuel containing acceptable deviations from nominal conditions and operating conditions up to the anticipated events (i.e., Limiting Safety System Set Points conditions). For example, higherloaded fuel will be tested to verify the performance of fuel at the maximum acceptable limit for segregation spots $(+20 \%)$. The potential of pinhole defects in the cladding to cause failure will be investigated, as well as whether the leakage of fission products to the coolant can be detected before the pinhole can lead to a blister. The threshold (temperature or energy input) at which the fuel plates sustain enough damage to make the element unusable and the release of fission products from the element in severe accidents will be addressed under the safety program, in close interaction with the fuels development task (see Sect. 5). 


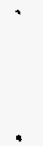




\section{INTERACTIONS WITH OTHER TASKS}

The fuel development and qualification task interacts with several other tasks for the qualification of the ANS fuel element for operation. These are outlined below. The safety tests are more integral with fuel performance and are described in Sect. 5.

\subsection{REACTOR CORE DEVELOPMENT-WBS 1.1.1}

The neutronic and thermal-hydraulic tasks combine to produce a fuel grading that will minimize the effects of power peaking and optimize core performance. The fuels task provides general guidance on fabricability, uncertainties, and other issues. After the fuel grading has been optimized, attempts will be made within this fuel development task to fabricate and inspect plates meeting those requirements. Some compromises may be necessary in the interests of feasibility of fabrication or inspection. In this likely event, working group meetings will work out compromises to optimize fabricability and performance.

The burnable poison material and distribution is also a joint effort among these tasks. The burnable poison distribution directly affects the fuel distribution. The material and distribution selected must also be fabricable, inspectable, and compatible with the fuel in the reactor.

The thermal-hydraulics task supports the design tasks by analyzing the effects on performance of uncertainties in the fuel fabrication such as fuel segregation, occurrence of nonbonds below the detectable limit, coolant-channel variations, and other manufacturing tolerances. The fuels task is defining the most conservative (worst) conditions that could exist within the fuel specifications. The analysis team then combines these conditions in a conservative manner and determines the effect on core conditions. Ideally, these worst-case combinations result in operating conditions within the accepted safe envelope of operating conditions for the reactor. If not, either further analysis or further inspections have to be done to remove some of the conservatism in the definitions, or analysis or testing has to show that the operating envelope can be safely extended.

\subsection{CORROSION TESTS AND ANALYSIS-WBS 1.1.3}

The fuels development task is coordinated with the corrosion testing task to ensure that the corrosion testing is accomplished on material representative of that in the fabricated elements. No changes have occurred in the cladding composition or condition from that used in HFIR. If changes were to prove desirable from a fabrication standpoint, the impact on corrosion and the possibility of further testing would of course have to be assessed. The corrosion testing task will provide data on oxide growth under conditions applicable to the design tasks so that the oxide film's effect on fuel temperatures can be calculated throughout the reactor cycle. 


\subsection{CRITICAL EXPERIMENTS-WBS 1.1.6}

The fuels task will supply a full core for the ANS critical experiments. The core will be prototypic, especially in regard to fuel distribution. Plates or sections of plates will be removable for analysis during the experiments.

\subsection{MATERIAL DATA, STRUCTURAL TESTS, AND ANALYSIS-WBS 1.1.7}

The fuels task will supply dummy plates for mechanical and flow testing to the fuel plate stability tests and analysis subtask. A full dummy core will be supplied by the fuels task for final flow testing to verify that the design will meet ANS requirements. This task will establish limiting temperatures for the fuel-plate cladding based on detailed structural analyses.

\subsection{FACILITY CONCEPTS-WBS 1.1.13}

The fuels task must interact with the facility concepts task to ensure that interfacing of the fuel elements with the reactor is compatible with the fabrication of the elements. The fuels task will supply a dummy core to this task for the fuel handling machine tests.

\subsection{OPERATIONS—WBS 1.7}

The fuels task will provide two dummy cores to the operations task for flow testing in the reactor prior to initial startup and for the facility mockup. 


\section{TESTING AND ANALYSIS OF FUEL PLATES UNDER TRANSIENT HEATUP CONDITIONS*}

\subsection{PURPOSE AND SCOPE}

Judging the adequacy of the ANS fuel plates requires a demonstration of adequate performance under both static and transient conditions. While an extensive fuels development program is in place to show that the fuel plate will stand up to the rigors of the reactor environment during normal steady state operation, there is no information related to silicidefueled plate response characteristics during transient conditions. Such information is required to ensure against fuel failure during transient heatup conditions, some of which are part of the design basis, and others of which are beyond the design basis (i.e., severe accident conditions) but play an important role in demonstrating reactor and plant safety. Such events include inadvertent control rod withdrawal, beam tube flooding, flow reduction because of pump seizure under full-power conditions, rapid depressurization caused by loss of primary coolant boundary integrity, fuel heatup from manufacturing defects, and flow blockage. No matter why the temperature excursion in the plate material occurs, heat being generated is not removed at the same rate. The degree of heatup depends upon the degree of mismatch between power flow and heat transfer.

Principal features to be evaluated are fuel plate response during rapid energy deposition conditions to determine damage thresholds. Currently, fuel failure or unacceptable performance thresholds have been based largely upon steady state considerations. If it is found that fuel performance degrades unacceptably for a given design-basis accident, it will become necessary to consider design modifications to the ANS system to reduce the possibility of that accident. Therefore, data obtained from transient testing could conceivably play a design role in addition to playing a very important role for safety evaluations.

Figure 5.1 is the logic diagram for the transient heating tests.

For various fuel geometries and densities, the transient testing and analysis program is to determine and understand the following:

- thresholds for excessive bowing and plate cracking,

- impact of manufacturing defects on failure thresholds,

- thresholds for blister formation,

- thresholds for melting and dispersion during which rapid fuel-coolant interactions may result,

- thresholds and rates of exothermic $\mathrm{U}_{3} \mathrm{Si}_{2}-\mathrm{Al}$ chemical reactions,

- thermal-to-mechanical energy conversion during any rapid fuel-coolant interactions upon fuel-plate fragmentation, and

- threshold and rate of any energetic aluminum-water interactions (ignition).

"This section, prepared by R. P. Taleyarkham, describes work supported by the ANS Safety Program under WBS 1.2.3. 


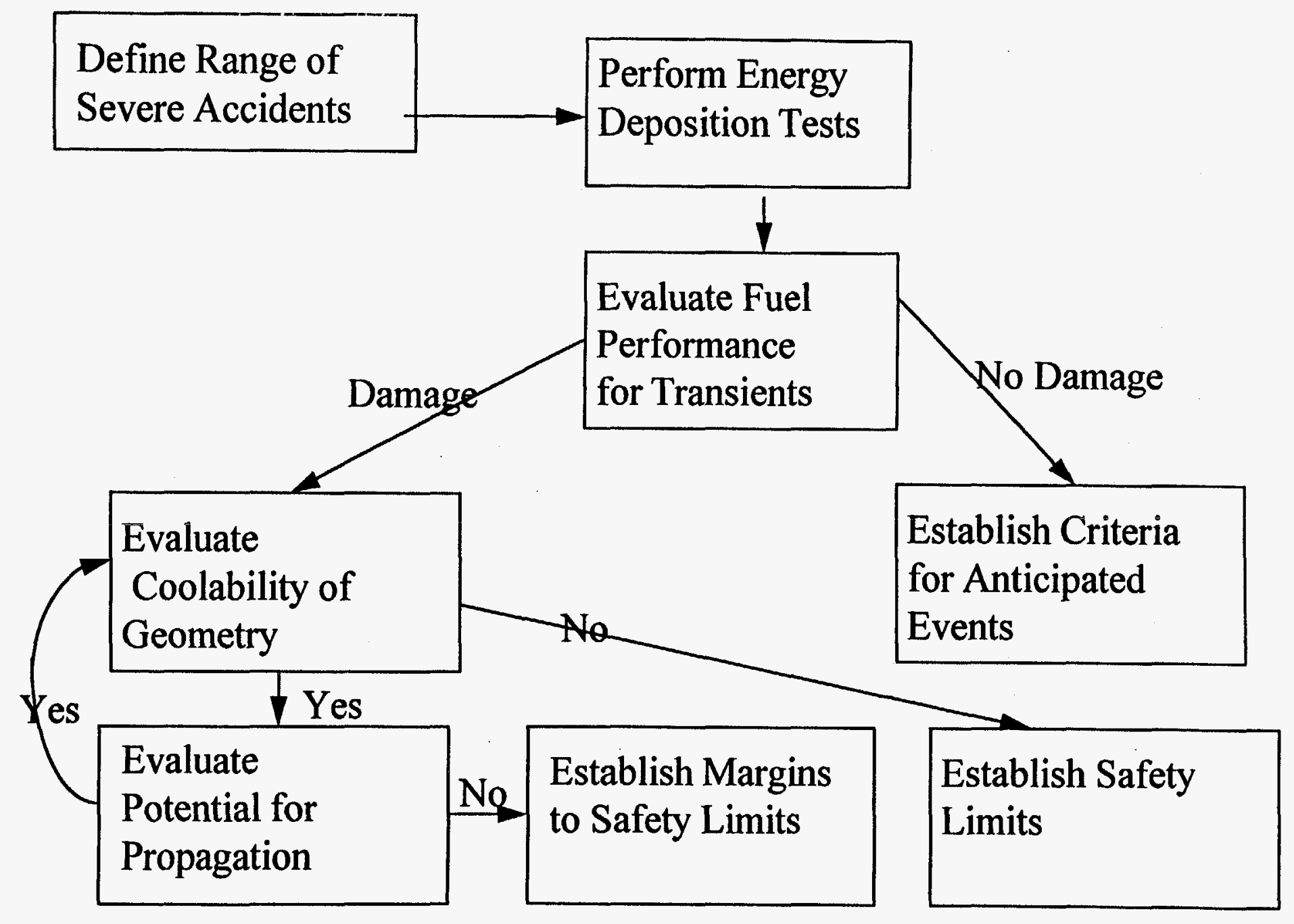

Fig. 5.1. Logic diagram for the transient heating tests for ANS. 
Then, preirradiated plates will be subjected to the same tests to determine both the impact of preirradiation on the above thresholds and the rate of fission product release during the events.

Testing will be as prototypic as practicable. The fuel plates and the plate spacing will be as close as possible to those to be used in the actual ANS core.

\subsection{WORK ELEMENTS}

Testing of ANS fuel plates to evaluate performance characteristics under transient heatup conditions is being conducted in the Nuclear Safety Research Reactor (NSRR) of the Japan Atomic Energy Research Institute (JAERI). NSRR, a pulse-type research reactor located at Tokai, Japan, is capable of providing bursts of neutrons over short periods of time. Pulse profiles can be shaped over a wide range for achieving the desired energy deposition and, therefore, heatup effects.

Oak Ridge National Laboratory (ORNL) supplies miniplates manufactured to relevant technical specifications to JAERI for testing and examination. ORNL also supplies modeling and analysis support for experimentation planning, execution, and test data evaluation. The work elements are discussed below.

\subsubsection{Miniplates for Testing}

ANS fuel miniplates are manufactured to meet technical specifications agreed upon between ORNL and JAERI. The miniplate geometry is shown in Fig. 5.2. Miniplates are manufactured by $B \& W$ to meet technical specifications outlined in Table 5.1. In the base-line design, the ANS fuel plate is composed of a fuel meat region in which the fueled section thickness varies between a maximum approximately $0.71 \mathrm{~mm}$ and a minimum of $0.1 \mathrm{~mm}$. The variation is such that the fueled section of thickness equal to $0.71 \mathrm{~mm}$ is close to centered in the meat, whereas, the thinnest section is off center, as shown in Fig. 5.2. The impact of this geometry variation may cause unforeseen effects on fuel-plate damage thresholds. Therefore, the testing and analysis plan calls for evaluating the performance of fuel plates that have the fueled meat centered as well as off center. The fuel fabrication development program is attempting to produce fuel in which the thinnest section of meat is also centered. If this effort is successful, the testing of off-center plates can be deleted.

Since only LEU can be shipped to JAERI, it is not possible to deposit sufficient energy to evaluate fuel-plate performance under steam-explosion conditions with the base-line fuel-density loading. Therefore, ANS miniplates with fuel-plate density increased from about $1.3 \mathrm{Mg} / \mathrm{m}^{3}$ to $4.8 \mathrm{Mg} / \mathrm{m}^{3}$ will be included. The higher density will be utilized for centered as well as off-center fuel meat geometries. The design parameters for the four different types of proposed miniplate types are shown in Table 5.2.

Some of the miniplates tested in NSRR (either with or without preirradiation) will have intentionally engineered defects to simulate the effect of undetected manufacturing defects such as dents, nonbonds, and streaking. The precise quantity and type of such miniplates are not yet determined. 
$130.0+/-0.5$

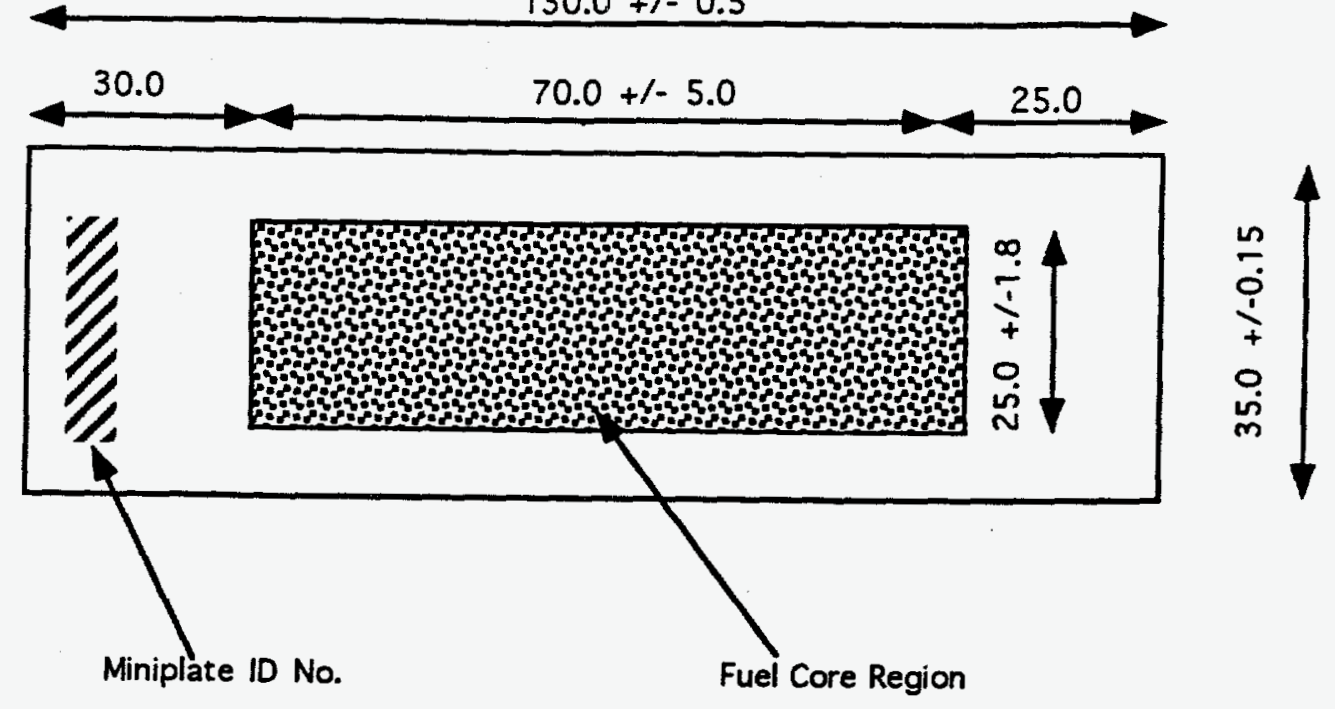

15 (max)

$m$
0
0
$⿱ 亠 1$
+
$n ̃ n$
-1

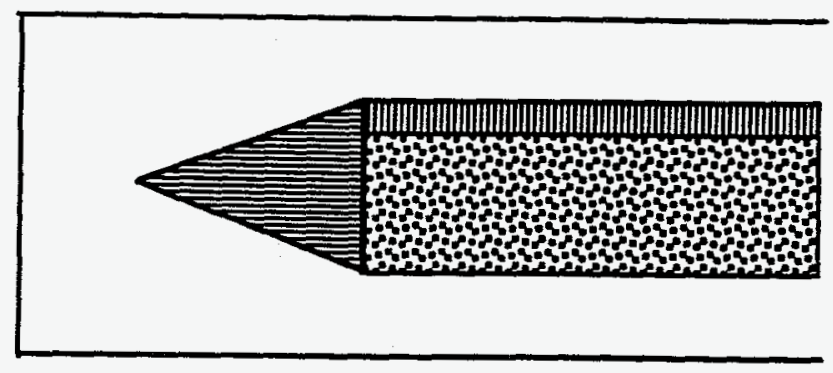

E

$E$

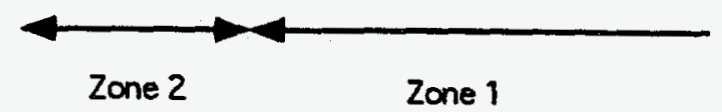

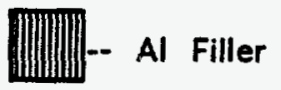

Fueled Meat

\section{NOTES:}

All dimensions in $\mathrm{mm}$.

tc $=$ cladding thickness $=0.255 \pm 0.02$.

$\mathrm{tfm}=$ fueled meat thickness (see Table 5.2 for details of ANS miniplates.

$\mathrm{tm}=$ total fuel meat thickness $=0.76 \pm 0.03$.

Fig. 5.2. Schematic representation of ANS miniplates for testing in NSRR. 
Table 5.1. Testing and inspection criteria for ANS miniplates

\begin{tabular}{|c|c|c|c|}
\hline Inspection item & Inspection method & Acceptance criteria & Sampling ratio \\
\hline U-235 content & Weighing & According to Table 5.2 & $100 \%$ \\
\hline Bonding test & $\begin{array}{l}\text { Blister test } \\
\text { Ultrasonic test }\end{array}$ & $\begin{array}{l}\text { 1. No blisters } \\
\text { 2. Combined defect shall be }<1.0 \mathrm{~mm} \text { diam }^{a} \text { in fissile area } \\
\text { 3. Combined defects shall be }<2.5 \mathrm{~mm} \text { diam }^{a} \text { outside of fissile area }\end{array}$ & $100 \%$ \\
\hline Radiography & $\begin{array}{l}\text { X-ray film using } \\
\text { magnification } \\
\text { glass and slide } \\
\text { calliper }\end{array}$ & $\begin{array}{l}\text { 1. Dimensions as per Fig. } 5.1 \\
\text { 2. Stray particle on radiograph }<0.5 \mathrm{~mm}^{2} \text { diam }^{a} \\
\text { 3. Any fuel plates with stray particles in following areas will be rejected: } \\
\text { a. Within } 2 \mathrm{~mm} \text { from longitudinal ends of fuel plate } \\
\text { b. Within } 3 \mathrm{~mm} \text { from lateral ends of fuel plate } \\
\text { c. Within } 1 \mathrm{~mm} \text { from the plate number }\end{array}$ & $100 \%$ \\
\hline $\begin{array}{l}\text { U- distribution } \\
\text { test }^{b}\end{array}$ & $X$-ray film & $\begin{array}{l}\text { 1. } \pm 15 \% \text { of average values in Zone } 1 \text { (Fig. } 5.1 \text { ) } \\
\text { 2. }+20 \%,-100 \% \text { of average values in Zone } 2 \text { (Fig. } 5.1 \text { ) }\end{array}$ & $100 \%$ \\
\hline $\begin{array}{l}\text { Dimensional } \\
\text { inspection }\end{array}$ & $\begin{array}{l}\text { Micrometer, slide } \\
\text { callipers }^{a}\end{array}$ & Dimensions as per Fig. 5.1 and Table 5.2 & $100 \%$ \\
\hline $\begin{array}{l}\text { Surface } \\
\text { contamination }\end{array}$ & Smear method & $<10 \mu \mathrm{g} \mathrm{U} / \mathrm{cm}^{2}$ or ANS specification, whichever is less & $100 \%$ \\
\hline Visual inspection & $\begin{array}{l}\text { Visual and depth } \\
\text { meter of defect }\end{array}$ & $\begin{array}{l}\text { 1. In fissile area: }<80 \mu \mathrm{m} \\
\text { 2. Out of fissile area: }<200 \mu \mathrm{m}\end{array}$ & $100 \%$ \\
\hline $\begin{array}{l}\text { Cladding and fuel } \\
\text { core inspection }\end{array}$ & $\begin{array}{l}\text { Destructive } \\
\text { test }\end{array}$ & $\begin{array}{l}\text { 1. Average clad thickness shall be } \pm 0.02 \mathrm{~mm} \text { of average in Zone } 1^{a} \\
\text { 2. Minimum cladding thickness shall conform to ANS core fuel plate specifications } \\
\text { 3. Fuel meat thickness shall be within } \pm 0.02 \mathrm{~mm}\end{array}$ & $\begin{array}{l}\text { One sample } \\
\text { from each } \\
\text { of four batches } \\
\text { of miniplates }\end{array}$ \\
\hline Metallography & $\begin{array}{l}\text { Destructive } \\
\text { test }\end{array}$ & Constituents will meet ANS fuel core plate material constitution specifications & $\begin{array}{l}\text { One sample from } \\
\text { above item }\end{array}$ \\
\hline Void content & $\begin{array}{l}\text { Immersion } \\
\text { density method }\end{array}$ & Variation within 2 to $10 \mathrm{vol} \%{ }^{a}$ & $100 \%$ \\
\hline Tensile test & $\begin{array}{l}\text { Manufacturer } \\
\text { method of choice }\end{array}$ & $\begin{array}{l}\text { No acceptance criteria; parameters to be tested for: yield strength, tensile strength, elongation, and Young's } \\
\text { Modulus }\end{array}$ & $\begin{array}{l}\text { One sample } \\
\text { from each } \\
\text { of four batches }\end{array}$ \\
\hline
\end{tabular}

"Use ANS fuel plate specifications if different than value cited.

${ }^{b}$ Scanning to be conducted over entire fuel core surface. 
Table 5.2. Design parameters of ANS miniplates for NSRR test ${ }^{\mathrm{a}}$

\begin{tabular}{lrrrr}
\hline & \multicolumn{4}{c}{ Miniplate } \\
\cline { 2 - 5 } \multicolumn{1}{c}{ Parameter } & ANS 1.1 & ANS 2.2 & ANS 2.1 & ANS 2.2 \\
\hline Enrichment, \% & 19.76 & 19.76 & 19.76 & 19.76 \\
Aluminum filler thickness, mm & 0.00 & 0.40 & 0.00 & 0.40 \\
Total meat thickness, mm & 0.76 & 0.76 & 0.76 & 0.76 \\
Cladding thickness, mm & 0.25 & 0.25 & 0.25 & 0.25 \\
Total plate thickness, mm & 1.27 & 1.27 & 1.27 & 1.27 \\
Mass of ${ }^{235} \mathrm{U}, \mathrm{g}$ & 0.37 & 0.17 & 1.26 & 0.60 \\
Mass of $\mathrm{U}, \mathrm{g}$ & 1.86 & 0.88 & 6.38 & 3.02 \\
Mass of $\mathrm{U}_{3} \mathrm{Si}_{2}, \mathrm{~g}$ & 2.01 & 0.95 & 6.89 & 3.26 \\
Mass of fuel meat, $\mathrm{g}$ & 5.10 & 2.41 & 8.92 & 4.22 \\
Mass of aluminum in fuel meat, $\mathrm{g}$ & 3.09 & 1.46 & 2.03 & 0.96 \\
Mass of aluminum filler, $\mathrm{g}$ & 0.00 & 1.89 & 0.00 & 1.89 \\
Total mass of meat, $\mathrm{g}$ & 5.10 & 4.30 & 8.92 & 6.11 \\
Fuel meat volume, cc & 1.33 & 0.63 & 1.33 & 0.63 \\
Total meat volume, cc & 1.33 & 1.33 & 1.33 & 1.33 \\
${ }^{235} \mathrm{U}$ density in fuel meat, $\mathrm{g} / \mathrm{cc}$ & 0.28 & 0.28 & 0.95 & 0.95 \\
$\mathrm{U}$ density in fuel meat, $\mathrm{g} / \mathrm{cc}$ & 1.40 & 1.40 & 4.80 & 4.80 \\
$\mathrm{U}_{3} \mathrm{Si}{ }_{2}$ density in fuel meat, g/cc & 1.51 & 1.51 & 5.18 & 5.18 \\
Fuel meat density, g/cc & 3.83 & 3.83 & 6.70 & 6.70 \\
Mass of miniplate, $\mathrm{g}$ & 17.11 & 14.43 & 20.93 & 16.23 \\
\hline
\end{tabular}

"Density of aluminum assumed $=2.7 \mathrm{~g} / \mathrm{cc}$, density of $\mathrm{U}_{3} \mathrm{Si}_{2}$ assumed $=12.2 \mathrm{~g} / \mathrm{cc}$. 


\subsubsection{Miniplate Irradiation}

ANS miniplates employed for the first several tests have not been preirradiated. Initial testing is being done with fresh plates only. The important effects of plate preirradiation will be clarified by testing beginning in FY 1997. ANS miniplates (type and quantity not yet determined) will be preirradiated in one or more of JAERI's material testing reactors. Capsule design and fabrication, preirradiation, cask design, qualification and fabrication, and handling and transport to the NSRR for pulse testing will be conducted by JAERI staff. Currently, it is expected that preirradiation of ANS miniplates in JAERI reactors will begin near the end of FY 1995 or in early FY 1996.

\subsubsection{Testing in Nuclear Safety Research Reactor}

ANS miniplates are placed into a capsule before testing in the NSRR. Figure 5.3 shows a schematic representation of a sample capsule and its internals for fresh miniplates. For preirradiated miniplates, the test capsule is expected to be double-walled. The miniplate configuration to be tested consists of either a single fueled plate or a three-plate cluster. The plates are held rigidly only at the base. A maximum of five thermocouples are spot welded to the face of each fueled plate. An additional thermocouple is placed in the water coolant. A sensor at the water-air interface senses motion of the water column to enable the evaluation of the kinetic energy imparted to the water column during explosive events. Cover gas can be sampled to detect hydrogen production, if any.

The testing process is initiated by actuating the appropriate control rod of the NSRR, thereby introducing the desired pulse shape of the neutron burst. The resultant fissioning in the miniplates causes rapid heat generation. Data acquisition from capsule instrumentation continues for several seconds.

Several days after completion of the power burst in the NSRR, the capsules are opened and the test specimens are subject to nondestructive and destructive examination. Examination includes gamma ray sampling at various intervals and distances, visual examination, dimensional measurements, sample preparation (after cutting) for evaluation by metallography, SEM, and $\mathrm{x}$-ray. For preirradiated plates, sampling and analyses for volatile and nonvolatile fission products will be included.

\subsubsection{Modeling and Analysis}

Modeling and analysis are required for understanding test data and for properly applying it to full-scale reactor conditions. Currently, modeling and analysis work is done in two areas. The first area is detailed modeling and analysis of thermal hydraulics in a threedimensional framework, using the HEATING-7 code and developed models for surface boiling heat transfer. Insight derived from this area not only is useful for the second area, but also provides information necessary to materials science experts in understanding onset and rates of exothermic reactions between $\mathrm{U}_{3} \mathrm{Si}_{2}$ and $\mathrm{Al}$. Modeling in this area is supplemented by separate modeling of heat-transfer phenomena surrounding individual fuel particles. Results of these analyses provide the appropriate modeling capability for application to actual fuel plate response to different distributions of fuel (and therefore, heat generation) because of heterogeneities or other causes. 


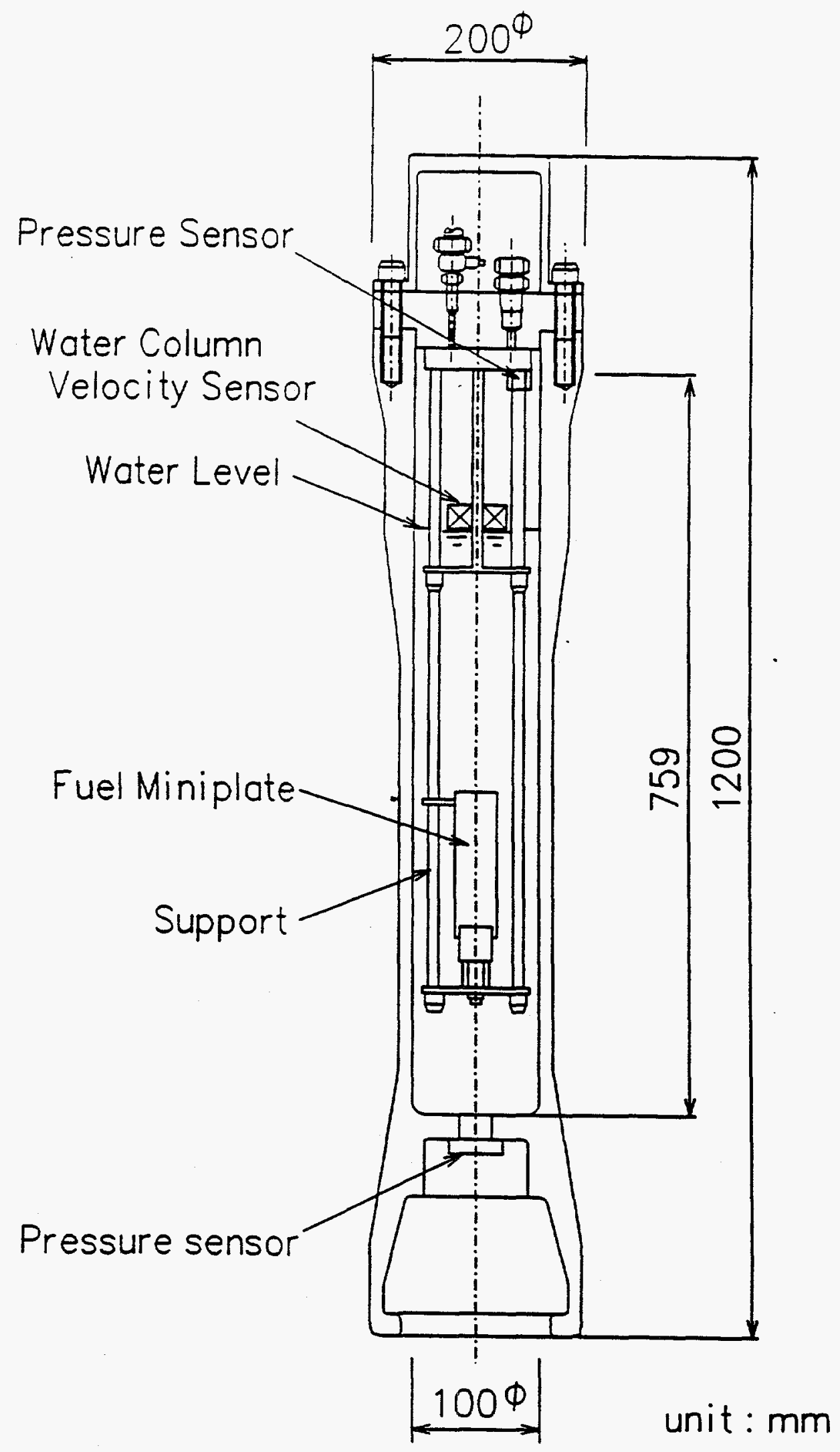

Fig. 5.3. Schematic representation of the NSRR test capsule with ANS miniplate. 
The second area of work is developing the capability to model and analyze thermal/structural response behavior during rapid thermal-hydraulic transients involving shock waves, including investigation of cracking, bowing, and material dispersion. This process uses analytical models in conjunction with the CTH code system, ${ }^{9}$ or with the RHALE code system, a three-dimensional shock wave physics code under development at Sandia National Laboratory. As may be expected, conducting combined heat transfer and structural analysis through material phase-change phenomena and breakup is complicated. Therefore, this area is being addressed in stages, starting with simulations in two dimensions and assuming uniform fuel meat composition. Then the effects of fuel meat heterogeneity and other variables are modeled. The end product of this work is envisioned to be a modeling capability that has been validated against scaled (NSRR) data and that can then be used to evaluate the response of full ANS plates under different transient conditions, specifically for estimation of failure thresholds and for severe accident conditions.

This dual modeling and analysis capability is also useful for experiment planning and design purposes.

In addition, investigation is being made into metallurgical phenomena, primarily the formation of compounds and eutectics by chemical interactions between $\mathrm{U}_{3} \mathrm{Si}_{2}$ and aluminum, which become rapid at approximately $580^{\circ} \mathrm{C}$. Metallurgical examination coupled with analyses provide useful information related to the extent and rates of exothermic reactions. The analysis of metallurgical aspects is done principally at ANL.

\subsubsection{Testing Program}

Testing in NSRR with ANS miniplates was initiated during FY 1993 and is continuing. During FY 1993 two tests were conducted. These tests were conducted with single miniplates at different energy deposition levels. During FY 1994 five plates have been tested. Three FY 1994 tests were conducted with single miniplates, and one was conducted with a cluster of three plates also to evaluate the importance of geometry, specifically, the presence of a narrow gap of water rather than a relatively large pool. Five additional plates are to be shipped to JAERI in July 1994. Testing is to begin in either late FY 1994 or early FY 1995.

Table 5.3 provides a summary of the tentative testing program. As noted, testing will continue with unirradiated miniplates through FY 1997. In FY 1998 NSRR testing will begin with miniplates irradiated in JAERI's research reactors beginning in late FY 1995 or early FY 1996. The preirradiation is expected to take place in JAERI's research reactors for a period of about two years. It is expected that an average of five to six experiments per year will be conducted with ANS miniplates from FY 1994 through FY 1999, for a total of about 40 test data points. 
Table 5.3. Tentative testing program for ANS miniplates in NSRR

\begin{tabular}{|c|c|c|c|}
\hline $\begin{array}{l}\text { Fiscal } \\
\text { year }\end{array}$ & $\begin{array}{c}\text { Number } \\
\text { of tests }\end{array}$ & $\begin{array}{l}\text { Preirradiated } \\
\text { ANS plates }\end{array}$ & Test and activities \\
\hline 1993 & 2 & No & Shakedown Tests \\
\hline 1994 & 5 & No & $\begin{array}{l}\text { Evaluation of effects of homogeneity and gap spacing on } \\
\text { failure thresholds, plate bowing and melting }\end{array}$ \\
\hline 1995 & $5-6$ & No & $\begin{array}{l}\text { Evaluation on impact of manufacturing defect; effects of } \\
\text { higher energy deposition to note effects of dispersion, } \\
\text { explosions, ignition and high-temperature melting }\end{array}$ \\
\hline 1996 & $5-6$ & No & $\begin{array}{l}\text { Begin preirradiation of ANS miniplates in JAERI reactors; } \\
\text { testing with fresh miniplates to evaluate effects of intentional } \\
\text { manufacturing defects, and skewed fuel meat distribution in } \\
\text { failure thresholds and energetics }\end{array}$ \\
\hline 1997 & $5-6$ & No & $\begin{array}{l}\text { Continue preirradiation of ANS miniplates; testing of fresh } \\
\text { miniplates to evaluate effect of plate clusters and with high- } \\
\text { density fueled plates to obtain higher energy deposition for } \\
\text { steam explosion energetics studies }\end{array}$ \\
\hline 1998 & $6-7$ & Yes & $\begin{array}{l}\text { Begin NSSR tests to evaluate impact of preirradiation on } \\
\text { failure thresholds, effect of manufacturing defects, melt } \\
\text { progression, and steam explosion energetics }\end{array}$ \\
\hline 1999 & $6-7$ & Yes & $\begin{array}{l}\text { Continue NSRR tests to evaluate impact of preirradiation on } \\
\text { failure thresholds, effect of manufacturing defects, melt } \\
\text { progression, and steam explosion energetics }\end{array}$ \\
\hline
\end{tabular}




\section{SCHEDULE AND COSTS}

\subsection{FUEL DEVELOPMENT-WBS 1.1.2}

The fuel development WBS element contains two major project milestones:

1. Complete the fuel-element design specification by June 1996, to allow the Title II design of the reactor system to proceed on schedule.

2. Complete the fuel performance report by June 2000 , to allow approximately two years of review before the publication of the final safety analysis report (FSAR).

The fuel development activity is divided into 12 level-four WBS tasks, summarized in Table 6.1. Most of this work will be performed by ANL, B\&W, and ORNL. The total estimated costs for this activity over the 9-year period covered by this research and development plan are given in Fig. 6.1, and the associated schedules are shown in Fig. 6.2. Note that the expense costs are associated with initial concept developments, fabrication and performance restrictions, the analyses and documentations that directly support preliminary (Title I) and detailed (Title II) design activities, support for the fuel development sections of the FSAR, and the effort and analytical tools needed to package and document the fuel performance in a form required by the operational staff as a transition to the operation of the facility. The line item costs include the various tasks needed to define the production-mode fabrication process and to purchase some tooling and required inspection equipment. These costs do not include any of the other activities associated with fuel qualification, such as the safety, corrosion, and structural tests.

\subsection{TRANSIENT HEATUP TESTING}

The true cost of tests and analyses being conducted in the JAERI facilities and at ORNL and B\&W can only be estimated, since the ANS Project is funding only that portion that involves the manufacturing and shipping of miniplates and the conduct of modeling and analysis work. This section breaks costs for conducting all the planned tests into two categories.

\subsubsection{Cost to Advanced Neutron Source Project}

The total cost to the ANS Project from FY 1993 through FY 2001 will be $\$ 2.2 \mathrm{M}$. This includes manpower costs $(\sim \$ 1.6 \mathrm{M})$ associated with interfacing with JAERI staff for experiment planning and design, test-matrix development, and modeling and analysis support of experimental data. Plate fabrication and shipment costs are $\sim \$ 0.6 \mathrm{M}$. The costs for metallurgical analyses conducted by the ANL staff is $-\$ 0.4 \mathrm{M}$ and is included in the overall fuels development program above. 
Table 6.1. Level-four work breakdown structure tasks for fuel development

\begin{tabular}{|c|c|}
\hline WBS & Task description \\
\hline 1.1.2.1 & $\begin{array}{l}\text { Selection and verification of fuel and cladding-The purpose of this task is to } \\
\text { review the existing data and to select the fuel type and clad type most amenable } \\
\text { to the objectives of the ANS }{ }^{a} \text { Project. The product of this task would be the } \\
\text { identification of the primary and backup fuel and clad materials. This task is } \\
\text { presently assumed to be complete. Primary fuel and clad materials and backup } \\
\text { fuel materials have been identified. At present no backup cladding material is } \\
\text { considered. If a backup cladding material for a change in the primary fuel or } \\
\text { cladding material is determined to be necessary, this task will be reopened. }\end{array}$ \\
\hline 1.1.2.2 & $\begin{array}{l}\text { Capsule irradiation tests-Capsules containing small quantities of individual fuel } \\
\text { particles will be irradiated in the target region of the HFIR. The very small } \\
\text { amount of fuel and the high thermal flux will allow burnup rates approaching } \\
\text { those expected in the ANS. Temperatures typical of the ANS will be achieved } \\
\text { with gamma heating and gas gaps. Evaluation of the fuel particles for structural } \\
\text { stability and morphology of the fission gas bubbles will be done by } \\
\text { metallography and scanning electron microscopy. }\end{array}$ \\
\hline 1.1.2.3 & $\begin{array}{l}\text { Miniplate irradiation tests-Miniplates will be tested in the target and/or reflector } \\
\text { of the HFIR to allow examination of plate swelling, fuel-matrix, burnable poison, } \\
\text { and meat-cladding interactions under conditions similar to those expected in the } \\
\text { ANS. }\end{array}$ \\
\hline 1.1 .2 .4 & $\begin{array}{l}\text { Irradiation damage simulation studies and fuel performance modeling-Since no } \\
\text { existing irradiation facility has the capability to irradiate prototype ANS fuel } \\
\text { under prototypic ANS conditions, a fuel performance model must be used to } \\
\text { predict fuel performance at or beyond ANS operating conditions. Although the } \\
\text { average burnup rate can be approached in the irradiation tests discussed, the peak } \\
\text { burnup rate in the ANS fuel cannot be duplicated in any reactor. The irradiation } \\
\text { damage simulation by ion bombardment at very high dose rates will allow a } \\
\text { determination of whether the irradiation behavior will change drastically at these } \\
\text { higher burnup rates. These data, along with data from the in-reactor irradiations, } \\
\text { will be used to develop and validate the fuel performance model. }\end{array}$ \\
\hline 1.1 .2 .5 & $\begin{array}{l}\text { Final performance report-This task provides the integration of the data from the } \\
\text { various fuel development subtasks in a documented form. }\end{array}$ \\
\hline 1.1.2.6 & $\begin{array}{l}\text { Plate and fuel element fabrication-The ANS uses a newly developed fuel } \\
\text { compound, } \mathrm{U}_{3} \mathrm{Si}_{2} \text {. Development is required to determine the homogeneity levels } \\
\text { achievable for the volume fractions of interest. At present the ANS requires both } \\
\text { radial and axial fuel-loading gradients. The achievement of the desired gradients } \\
\text { with sufficient confidence and verification requires demonstration of modified (or } \\
\text { new) fabrication techniques. }\end{array}$ \\
\hline
\end{tabular}


Table 6.1. (continued)

\begin{tabular}{|c|c|}
\hline WBS & Task description \\
\hline 1.1.2.7 & $\begin{array}{l}\text { Dummy plate and element fabrication-This task is to fabricate a dummy fuel } \\
\text { element (A1-6061 plates with no fuel) for use in flow experiments. In addition, this } \\
\text { task will provide prototype fuel plates for structural testing. }\end{array}$ \\
\hline 1.1 .2 .8 & $\begin{array}{l}\text { Prototype fuel element fabrication for critical experiments-This task is to fabricate } \\
\text { a fully loaded prototype ANS core for use in performing critical experiments. The } \\
\text { activities of this task include powder die and fixture development, engineering, and } \\
\text { manufacture of an upper and lower fuel element. }\end{array}$ \\
\hline 1.1.2.9 & $\begin{array}{l}\text { Full-size plate irradiation-This task will complete the irradiation testing program } \\
\text { for the ANS fuel with the irradiation of a few full-size plates. }\end{array}$ \\
\hline 1.1.2.10 & $\begin{array}{l}\text { Burnable poison selection and testing-This task will supply the material } \\
\text { evaluations necessary to qualify the burnable poison material selection. Some } \\
\text { demonstration of techniques to fabricate the burnable poison sections also will be } \\
\text { included in this task. }\end{array}$ \\
\hline 1.1.2.11 & $\begin{array}{l}\text { Fuel element fabrication-This task will provide the effort needed to establish the } \\
\text { production mode fabrication process. Although some cores may be fabricated under } \\
\text { this task, it is not clear that they will be suitable for use in the ANS reactor. }\end{array}$ \\
\hline 1.1.2.12 & $\begin{array}{l}\text { HFIR Experimental Silicide Core-This task will support the safety analyses and } \\
\text { documentation necessary to support the use of an experimental core in HFIR } \\
\text { containing } \mathrm{U}_{3} \mathrm{Si}_{2} \text { fuel, along with a limited postirradiation examination. }\end{array}$ \\
\hline
\end{tabular}

${ }^{a}$ ANS $=$ Advanced Neutron Source

${ }^{b}$ HFIR $=$ High Flux Isotope Reactor

\subsubsection{Cost-Savings Estimates}

Costs for conducting equivalent tests in the United States were estimated in consultation with ANL, operator of the transient reactor test facility (TREAT), which has capabilities similar to those of NSRR. ANL staff estimated that the cost for conducting a single test in TREAT with unirradiated fuel plates would range from $\$ 1.5 \mathrm{M}$ to $\$ 2 \mathrm{M}$. Costs would be much larger, $\$ 3 \mathrm{M}$ or more per test, for preirradiated plates.

For approximately 28 tests without preirradiation and 12 tests with preirradiation, the cost of conducting equivalent tests in TREAT would be in the range of $\$ 78 \mathrm{M}$ to $\$ 85 \mathrm{M}$. This estimate does not include costs associated with preirradiation in a U.S. research reactor, hotcell work, cask preparation and qualification, transportation to TREAT, and, finally, disposal and cleanup. Thus, the total cost avoidance to DOE for JAERI testing is in the range of $\$ 80 \mathrm{M}$ to $\$ 90 \mathrm{M}$. It must be pointed out that these cost savings are not from existing or planned ANS Project funds, since the costs for conducting these tests in the U.S. was never in the ANS funding basis. 


\begin{tabular}{|c|c|c|c|c|c|c|c|c|c|c|c|c|c|c|}
\hline WBS & & & & Prior & & & & & & & & & & \\
\hline Level 3 & Level 4 & Description & Type & Years & 1995 & 1996 & 1997 & 1998 & 1999 & 2000 & 2001 & 2002 & 2003 & Total \\
\hline & & & & & & & & & & & & & & \\
\hline \multirow[t]{5}{*}{1.1 .2} & & Fuel Development & & & & & & & & & & & & \\
\hline & & & & & & & & & & & & & & \\
\hline & 1.1 .2 .1 & Selection and verification of fuel and cladding (Done) & Exp. & & & & & & & & & & & 0 \\
\hline & & & & & & & & & & & & & & \\
\hline & 1.1 .2 .2 & Capsule irradiation test & Exp. & & 196 & & & & & & & & & 196 \\
\hline & & & & & & & & & & & & & & 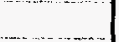 \\
\hline & 1.1.2.3 & Miniplate irradiation tests & Exp. & & 512 & 911 & 811 & 347 & 93 & & & & & 2674 \\
\hline & & & & & & & & & & & & & & \\
\hline & 1.1 .2 .4 & Irradiation damage simulation studies and fuel performance & Exp. & & 155 & 220 & 220 & 200 & 188 & 106 & 106 & & & 1195 \\
\hline & & & & & & & & & & & & & & \\
\hline & 1.1 .2 .5 & Final performance report & Exp. & & & & & & 41 & 41 & & & & 82 \\
\hline & & & & & & & & & & & & & & \\
\hline & 1.1.2.6 & Plate and fuel element fabrication & Exp. & & 389 & 479 & 479 & & & & & & & 1347 \\
\hline & & & & & & & & & & & & & & $\ldots$ \\
\hline & 1.1 .2 .7 & Dummy plate and element fabrication & Exp. & & 23 & 724 & 73 & & & & & & & 820 \\
\hline & & & & & & & & & & & & & & $\ldots$ \\
\hline & & & & & & & & & & & & - & & 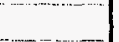 \\
\hline & 1.1.2.9 & Full-size plate irradiation & Exp. & & & 502 & 268 & 204 & & & & & & 974 \\
\hline & & & & & & & & & & & & & & \\
\hline & 1.1.2.10 & Bumable poison selection and testing & Exp. & & 50 & 52 & 52 & 52 & & & & & & 206 \\
\hline & & & & & & & & & & & & & & \\
\hline & 1.1 .2 .11 & Fuel element fabrication & $\operatorname{Lin} \theta$ & & & 1000 & 2210 & 2235 & 654 & 654 & 654 & & & 7407 \\
\hline & & & & & & & & & & & & & & 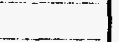 \\
\hline & 1.1 .2 .12 & HFIR Expermental Silicide Core & Exp. & & 173. & 372 & 392 & 200 & 218 & & & & & 1355 \\
\hline & & & & & & & & & & & & & & \\
\hline & & & & & & & & & & & & 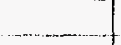 & ......... & \\
\hline & & Subtotals & Exp. & & 1498 & 3539 & 2849 & 1003 & 540 & 147 & 106 & 0 & 0 & 9682 \\
\hline & & & Line & & 0) & 1000 & 2210 & 2235 & 654 & 654 & 654 & 0 & of & 7407 \\
\hline & & & & & & & & & & & & & & \\
\hline & & Contingency & Exp. & & & 354 & 285 & 100 & 54 & 15 & 11 & & & $8+9$ \\
\hline & & & Line & & & 200 & 442 & 447 & 131 & 131 & 131 & & & 1482 \\
\hline & & & & & & & & & 1 & & & $\ldots$ & - & \\
\hline & & Total & Exp. & & 1498 & 3893 & 3134 & 1103 & 594 & 162 & 117 & 0 & $\underline{0}$ & 10501 \\
\hline & & & Line & & 0 & 1200 & 2652 & 2682 & 785 & 785 & 785 & 0 & 0 & 8889 \\
\hline & & Exp.+Line & & & 1498 & 5093 & 5786 & 3785 & 1379 & 947 & 902 & 0 & 의 & 19390 \\
\hline
\end{tabular}

Fig. 6.1. Summary of cost estimates for WBS 1.1.2, fuel development, in thousands of dollars. 


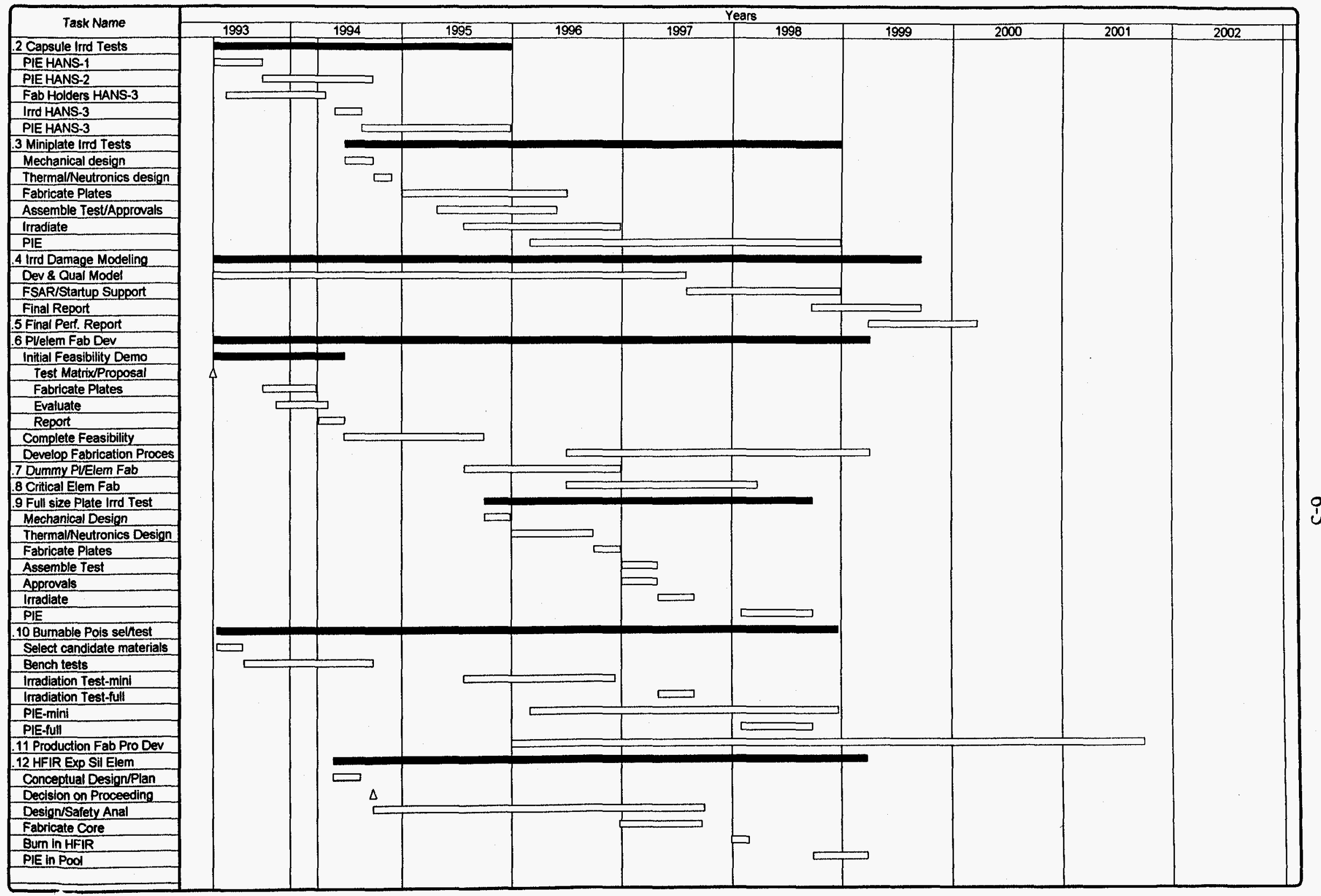

Fig. 6.2. Schedule for WBS 1.1.2, fuel development. 


\section{CONCLUSIONS}

A program is in place to develop and qualify fuel for ANS. The fuel core contains two elements similar to those of HFIR but with axial separation of the two elements. The fuel distribution within the plates in ANS is graded both axially and radially, not just radially as in the HFIR. The fuel compound for ANS is $\mathrm{U}_{3} \mathrm{Si}_{2}$, rather than the $\mathrm{U}_{3} \mathrm{O}_{8}$ used in HFIR. The use of $\mathrm{U}_{3} \mathrm{Si}_{2}$ dispersed in aluminum has previously been qualified for the conversion of mediumpowered research reactors to LEU. The conditions in ANS are outside the experience base for any research reactor fuel in terms of temperature, fission rate, and burnup. Therefore, a fabrication development and irradiation performance testing program is required to qualify the fuel for ANS. The available data indicate that the extension to ANS requirements from both a fabrication and performance perspective has a very high probability of success. The development and qualification programs are therefore success-oriented verification programs rather than exploratory.

The high confidence for success is based in part on the low volume fraction of fuel (0.15) required for the ANS design. If the design changes such that the volume fraction of the dispersed fuel phase is substantially increased (for example, to accommodate lower enrichment in the fuel), the major impacts would be in the areas of fabrication and irradiation performance qualification. As the volume fraction of fuel is increased, both fabrication and inspection become more difficult, and the probability of successfully qualifying the fuel in both fabrication and irradiation performance is decreased. The irradiation performance qualification would need to be strengthened in the miniplate irradiation testing subtask.

A comprehensive safety program is in place to obtain the data required to assess the postulated severe accidents. These experiments are designed to set safety limits for the reactor operation and to provide assessments of fuel damage in the event of severe accidents. 


\section{REFERENCES}

1. G. L. Copeland et al., Advanced Neutron Source Final Preconceptual Reference Core Design, ORNL/TM-11234, Martin Marietta Energy Systems, Inc., Oak Ridge Natl. Lab., August 1989, p.6.

2. Safety Evaluation Report Related to the Evaluation of Low-Enriched-Uranium Silicide-Aluminum Dispersion Fuel in Non-Power Reactors, U. S. Nuclear Regulatory Commission, July 1988.

3. F. J. Peretz, Conceptual Design Report-Summary, ORNL/ANS/INT-34/S1, Martin Marietta Energy Systems, Inc., Oak Ridge Natl. Lab., June 1992.

4. R. R. Hobbins, Idaho National Engineering Laboratory, Idaho Falls, Idaho, letter to C. D. West, Oak Ridge Natl. Lab., Feb. 19, 1992.

5. J. L. Snelgrove et al., The Use of $U_{3} S i_{2}$ Dispersed in Aluminum in Plate-Type Fuel Elements for Research and Test Reactors, ANL/RERTR/TM-11, Argonne National Laboratory, Chicago, October 1987.

6. G. L. Copeland et al., Performance of Low-Enriched $U_{3} S i_{2}$-Aluminum Dispersion Fuel Elements in the Oak Ridge Research Reactor, ANL/RERTR/TM-10, Argonne National Laboratory, Chicago, October 1987.

7. J. L. Snelgrove, G. L. Copeland, and G. L. Hofman, "Postirradiation Examination of ORR Demonstration Elements," pp. 151-60 in Proceedings of the 12th International Meeting Reduced Enrichment Research and Test Reactors, Berlin, 10-14 October 1989, Forschungszentrum Julich GmbH, Berlin, 1991.

8. G. L. Hofman, J. Rest, and J. L. Snelgrove, "A New Swelling Model and Its Application to Uranium Silicide Research Reactor Fuel," Proceedings of the 1992 International Meeting on Reduced Enrichment for Research and Test Reactors, Roskilde, Denmark, Sept. 27-Oct. 1, 1992.

9. J. N. McGlaun and S. L. Thompson, "CTH: A 3-Dimensional Shock Wave Physics Code," Int. J. of Impact Eng. 10, 251-360 (1990). 


\section{INTERNAL DISTRIBUTION}

$\begin{aligned} \text { 1. } & \text { B. R. Appleton } \\ 2 . & \text { R. L. Beatty } \\ 3-7 . & \text { J. H. Campbell } \\ 8 . & \text { J. E. Cleaves } \\ 9-13 . & \text { G. L. Copeland } \\ \text { 14. } & \text { K. Farrell } \\ \text { 15. } & \text { D. K. Felde } \\ \text { 16. } & \text { M. L. Gildner } \\ 17 . & \text { G. E. Giles, Jr. } \\ \text { 18. } & \text { H. A. Glovier } \\ \text { 19. } & \text { R. M. Harrington } \\ 20 . & \text { J. B. Hayter } \\ 21 . & \text { R. O. Hussung } \\ 22 . & \text { D. G. Morris } \\ 23 . & \text { D. L. Moses } \\ 24 . & \text { S. J. Pawel } \\ 25 . & \text { D. J. Peretz }\end{aligned}$
26.
C. C. Queen
27. P. L. Rittenhouse
28. R. E. Rothrock
29. D. L. Selby
30. R. P. Taleyarkhan
31. K. R. Thoms
32. P. T. Thornton
33. C. D. West
34. B. A. Worley
35. G. T. Yahr
36. G. L. Yoder
37. ORNL Patent Office
38. Central Research Library Document Reference Section
39. Y-12 Technical Library
40-41. Laboratory Records
42. Laboratory Records (RC)

\section{EXTERNAL DISTRIBUTION}

43-47. J. E. Mays, Research and Test Reactor Fuel Elements, Babcock and Wilcox Co., P.O. Box 785, Lynchburg, VA 24505.

48-52. J. L. Snelgrove, Coordinator, Engineering Applications, RERTR Program, Argonne National Laboratory, 9700 South Cass Avenue, Argonne, IL 60439.

53. U. S. Department of Energy, ANS Project Office, Oak Ridge Operations Office, FEDC, MS-8218, P. O. Box 2009, Oak Ridge, TN 37831-8218.

54-55. Office of Scientific and Technical Information, P. O. Box 62, Oak Ridge, TN 37831 